\title{
How beer created Belgium (and the Netherlands): the contribution of beer taxes to war finance during the Dutch Revolt
}

Koen Deconinck $^{\mathrm{a} *}$, Eline Poelmans ${ }^{\mathrm{a}, \mathrm{b}, \mathrm{c}}$ and Johan Swinnen ${ }^{\mathrm{a}}$

${ }^{a}$ LICOS Centre for Institutions and Economic Performance, University of Leuven (KU Leuven), Leuven, Belgium;

$b_{\text {Faculty of Economics and Business (FEB), University of Leuven }}$ (KU Leuven), Campus Brussels, Brussels, Belgium;

${ }^{c}$ Leuven Centre for Irish studies, University of Leuven (KU Leuven), Leuven, Belgium

Abstract:

The present-day border between Belgium and the Netherlands can be traced back to the separation of the Low Countries after the Dutch Revolt (1566-1648) against Spanish rule. The capacity to finance the escalating cost of war determined the outcome of this conflict. As Spain struggled to provide regular pay to its troops, its war efforts were often plagued by mutiny. In contrast, the Dutch Republic managed to raise large sums for its war budgets. As we show in this article, excise taxes on beer consumption were one of the largest income sources in Holland, the leading province of the Dutch Republic. Over the course of the Revolt, Dutch beer taxes brought in the equivalent of $29 \%$ of Spanish tax revenues on silver from America. Beer taxes thus played a crucial role in financing the Dutch Revolt which led to the separation of the Low Countries and, eventually, the creation of Belgium.

Keywords: taxation; beer; excises; Dutch Revolt; war finance

Published as: Deconinck, K; Poelmans, E. and Swinnen, J. (2016).“How Beer created Belgium (and the Netherlands): the contribution of beer taxes to war finance during the Dutch Revolt". In: Business History, 58(5), pp. 694-724. 


\section{Introduction}

In the past 20 years, economists and historians have increasingly emphasised the role of political institutions in economic development. ${ }^{1}$ An underlying theme is that 'good institutions' presuppose a stable and well-functioning state which respects fundamental rights of its inhabitants. While economists have tended to emphasise constraints on the ruler (such as the rule of law and accountability), empirical research also confirms the importance of state capacity for development. ${ }^{2}$ Given the existence of failed states' or severely malfunctioning states in many parts of the world, the question naturally arises how state formation historically occurred in Europe. Historians who studied this question point to the importance of warfare in the Early Modern era (c.,1450 - 1789). Frequent warfare created 'evolutionary' pressures for rulers to improve their military apparatus, including their methods of financing and organizing warfare. In turn, these rulers could subdue other rulers and thus expand their reach. Public finance was an essential aspect of this process of state formation, as states with a larger tax base had a military advantage over their competitors. ${ }^{3}$

In this article, we study war finance in the Dutch Republic during its formative period through the lens of taxation on beer. As we show, the fiscal revenues from beer taxes played a major role in giving the Dutch Republic the military power to break away from the Spanish-occupied Low Countries in the course of the Dutch Revolt (c.,1566- 1648), leaving the territory of present-day Belgium behind as the remainder of the Spanish Low Countries. The outcome of the Dutch Revolt was unusual, in that a small rebellious region eventually won its independence from the mighty Spanish Empire. As we document in this article, the explanation for this remarkable outcome lies in a combination of developments in war technology and the extraordinary capacity of the Dutch to finance the war. Because of technological developments and innovations in strategy and tactics, 
warfare during the Dutch Revolt was an increasingly capital-intensive undertaking. The capacity to finance war expenditures therefore became of paramount importance. The Spanish army in the Low Countries was constantly short of funds, which led to frequent payment arrears among its troops. As a result, demoralisation, desertion and mutinies undermined the Spanish position. The Dutch, on the other hand, could count on a superior system of public finance to obtain revenues. A substantial part of the Dutch taxation system consisted of taxes on beer. In fact, the excise tax on beer was one of the largest components of government revenues in Holland, the leading province in the Dutch Republic. Hence, beer taxes played a crucial role in giving the Dutch Republic the military power to break away from the Spanish-occupied Low Countries and thus in the determination of the present-day border between Belgium and the Netherlands, which largely follows the division between the Spanishoccupied and Dutch-occupied territories at the end of the Dutch Revolt. $^{4}$

To the best of our knowledge, we are the first to make this argument. In this article, we draw upon important contributions on the history of the Dutch wars of Independence and the emergence of the Dutch Republic; ${ }^{5}$ on the composition of the government finances of Holland and Spain during the Revolt; ${ }^{6}$ and on the history of beer in the Low Countries. ${ }^{7}$ Our argument is related to the analysis of John Nye on how beer taxes and wine tariffs were crucial for the development of the British Empire. ${ }^{8}$

The article is organized as follows. The next section presents a brief history of the Dutch Revolt and explains how the borders between present-day Belgium and the Netherlands were determined during the Dutch Revolt. The third and fourth section document the paramount importance of war finance in determining the outcome of military conquests during the Dutch Revolt. The fifth and sixth section discusses the Dutch system of public finance 
and documents the importance of beer excises in Holland. The seventh section then turns to an explanation of the importance of beer in financing the Revolt. The final section concludes.

\section{The origins of Belgium and its northern border}

Today's border between Belgium and the Netherlands has its roots in the Treaty of Münster (1648), ending a remarkable revolt which had started 80 years earlier. ${ }^{9}$ In the late sixteenth century, the Low Countries were part of the Spanish Empire under Philip II (Map 1, the entire region). As ruler of an empire 'on which the sun never set', Philip tried to centralise the administration of his empire in Madrid. Moreover, as a fervent catholic, Philip considered it his mission to suppress heresy throughout Europe. Both factors led to unrest in the Low Countries. Philip's attempts at centralisation threatened important privileges of the nobility and the towns. At the same time, his hostility to the growing Protestant faith troubled the cities of the Low Countries where the new religious ideas of the sixteenth century had found fertile ground. Spanish attempts to violate traditional privileges in order to increase taxes, together with their harsh repression of Protestantism, sparked a series of upheavals which culminated in a declaration of independence by several northern provinces in 1581, uniting themselves in the Dutch Republic. 10

The Dutch fight for independence against the Spanish lasted for 80 years, making it one of the longest revolts in European history. 11 During this struggle, the border between the Dutch Republic and the Spanish-occupied parts of the Low Countries moved regularly, as large territories changed hands several times. The Treaty of Münster (1648) put an end to the Dutch Revolt. ${ }^{12}$ It cemented the military positions at the time of the Treaty into the official borders between the Dutch Republic and the Spanish Empire, thus separating the northern Low Countries (the Dutch 
Republic) from the southern Low Countries (Figure 1).

\section{Figure 1. The Low Countries with the border of 1648.}

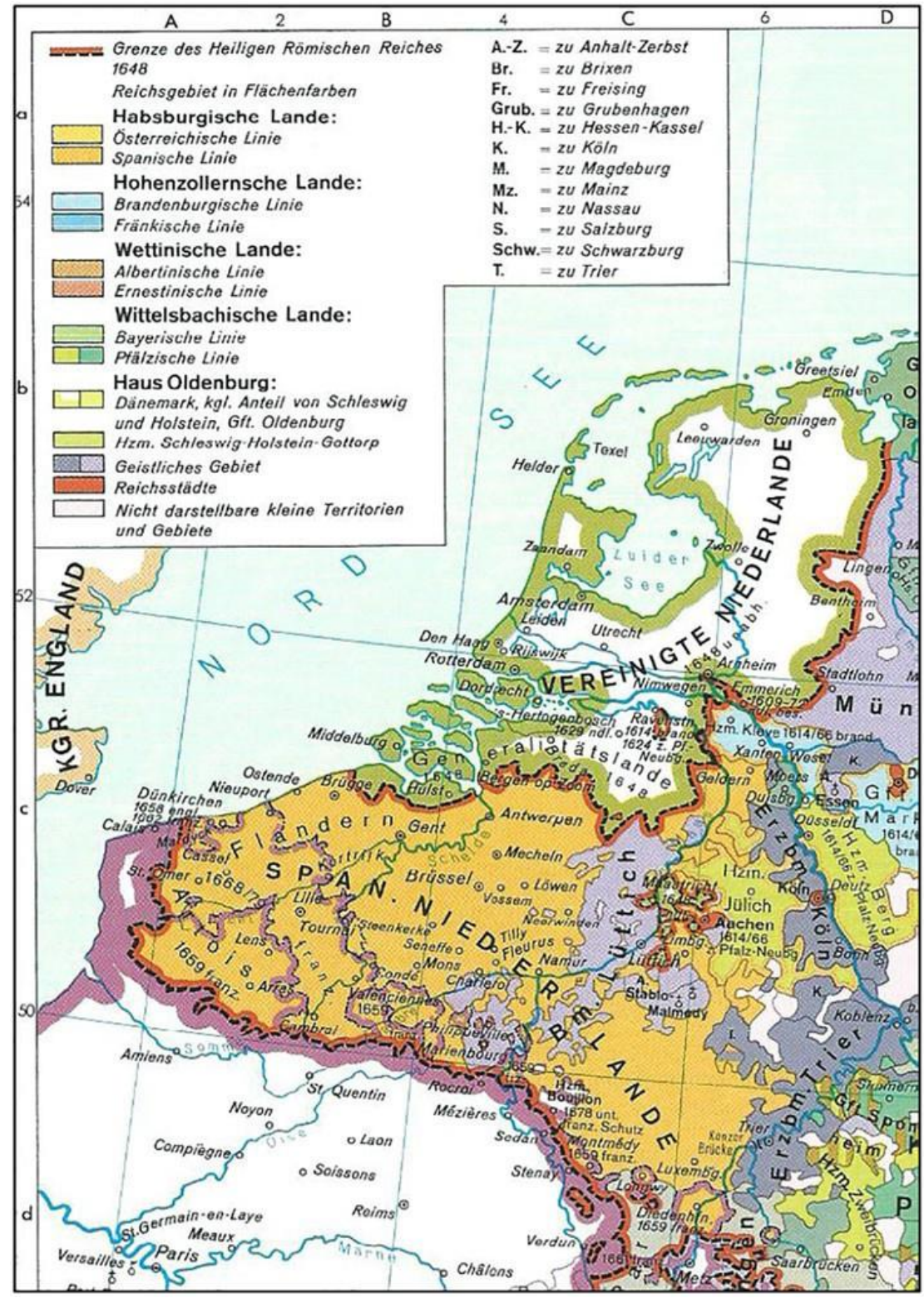

After 1648: top: The Dutch Republic (Republic of the Seven United Provinces); bottom: The Spanish Netherlands.

Source: Leisering, Putzger Historischer Weltaltlas (1997), 74 (detail). 
Initially, this border was largely artificial, in the sense that it was determined by military conquests and had little to do with geographical borders (such as rivers or other natural defenses) or pre-existing administrative borders. On both sides of the border, Dutch dialects were spoken, and both sides held large numbers of Catholics and Protestants. ${ }^{13}$ Moreover, the new border cut right through existing administrative units and provinces. For example, the province of Brabant was split up, with a northern part being occupied by the Dutch while the southern part of the province remained under Spanish control. ${ }^{14}$ Similarly, the Dutch controlled the north of Flanders which allowed them to block Antwerp's access to the sea. In both cases, the provincial capital, which contained the seat of the provincial government, remained in Spanish hands. 15

During and after the Revolt, however, the border created and magnified important cultural and institutional differences between the regions. ${ }^{16}$ For instance, while Antwerp had been one of the most important ports in Europe during the sixteenth century, the blockade of its port during the Revolt had completely undermined its position and shifted trade to Amsterdam, which took over Antwerp's leading position. Many artists, skilled workers and intellectuals migrated north at the end of the sixteenth and beginning of the seventeenth century, leading to a 'brain drain'. The Southern Low Countries declined in politics, economics and culture. ${ }^{17}$ The Dutch Republic, meanwhile, witnessed a cultural and economic golden age: “ ... the explosive expansion of its commerce which followed [from 1585 onwards] transformed the Republic into Europe's chief emporium and bestowed a general primacy in world commerce which was to endure for a century and a half'. 18

Although the 1648 border was initially rather arbitrary, by the early nineteenth century the separation had led to significant economic, 
political and cultural differences between the northern and southern Low Countries. These differences played a crucial role in the creation of Belgium and its northern borders. Following the French revolutionary wars and Napoleon's imperialism, both the Dutch Republic and the southern Low Countries became part of the French empire. After Napoleon's defeat, the Congress of Vienna (1815) reunited both regions in the United Kingdom of the Netherlands, as a buffer against further French aggression. ${ }^{19}$ However, the two regions had gone through radically different developments since their separation during the Dutch Revolt. This resulted in the break-up of the United Kingdom of the Netherlands in 1830, with the borders between the Netherlands and the newly formed Kingdom of Belgium coinciding largely with those established between the Dutch Republic and the Spanish Low Countries more than 180 years earlier (Figure 2). ${ }^{20}$ Thus, the Dutch Revolt not only led to the separation of the Low Countries, but the dividing line of 1648 today still to a large extent forms the border between Belgium and the Netherlands. ${ }^{21}$ 
Figure 2. Present-day borders between Belgium and the Netherlands.

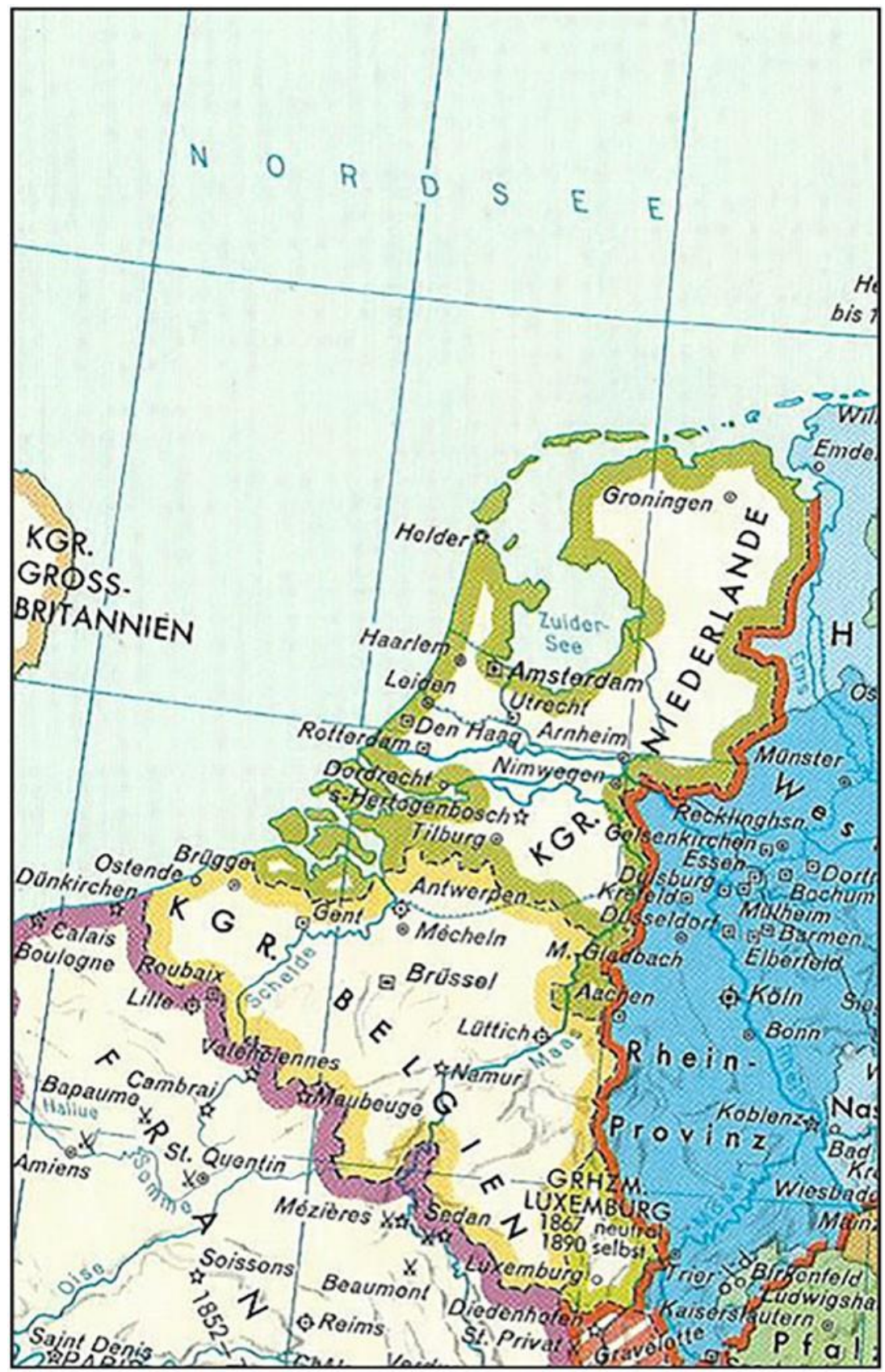

Source: Leisering, Putzger Historischer Weltaltlas, 9 (Detail). 


\section{The costs of the revolt and its unlikely outcome}

\subsection{The unlikely outcome of the Dutch Revolt}

The Spanish concessions obtained in the Treaty of Münster were a remarkable achievement for the Dutch, given the disadvantageous position they had started from.

To understand how advantageous the eventual settlement was to the Dutch, consider the difference between the demands of the Dutch and the Spanish at the beginning of the conflict and the final settlement in 1648. Initially, the Dutch rebels were willing to accept Spanish rule in return for religious liberties and respect for their traditional privileges. 22

By contrast, the Spanish aimed to reclaim the Low Countries entirely and reinstall the Catholic Church as the one true faith. ${ }^{23}$ Instead, the 1648 Treaty officially recognised the Dutch Republic as an independent state, with a territory that was even larger than it had occupied during much of the Revolt. While the Spanish held control over the important city of Antwerp, the Dutch kept possession of the north of Flanders which enabled them to block Antwerp's access to the sea. Additionally, the Dutch kept their overseas possessions and 'free navigation' in the East Indies. Moreover, Spain did not obtain any special treatment or advantages

for the Catholics in the Dutch Republic. ${ }^{24}$ The result obtained by the Dutch was 'one of the most remarkable achievements of the sixteenth and seventeenth centuries'. 25

This outcome is hard to imagine when considering the initial military situation and the length of the conflict. The Dutch Revolt was the longest uprising in modern European history. It was an unequal struggle, pitting the enormous Spanish empire against a handful of provinces and towns in the Netherlands. In 1574, a few years after the start of the uprising, the resistance consisted of only about 20 towns with a total population of some 75,000 people. ${ }^{26}$ 
The rebels faced a Spanish Empire with a large and well-trained army and wealthy colonies in America to finance the war. Moreover, at the beginning of the war, the Spanish troops were Europe's largest, best trained and best equipped military force. 27 Yet in the end, the Dutch Republic won.

The explanation for this remarkable outcome can be found in the changing nature of warfare during this period in European history and its financial implications.

\subsection{The sixteenth century 'military revolution' and its implications}

In the century leading up to the Dutch Revolt, the costs of fighting a war had largely increased due to changes in the scale and nature of warfare. This 'military revolution' had several aspects. 28 One factor was the increasing professionalisation of armies. Whereas earlier battles had been fought with armies raised for the occasion, rulers turned to maintaining well-trained and permanent armies, organised into units with standardised weapons (and sometimes uniforms). In addition, there were changes in tactics and strategy, as armies started using more complex arrangements of troops. Yet, the most important factor was the consequence of technological and architectural innovations. Somewhat paradoxically, technological progress in artillery made it more difficult to swiftly conquer towns. Improved cannons made it relatively easy to break medieval fortifications which typically consisted of walls that were high but relatively thin. In response, military architects designed new fortifications which could withstand artillery attacks and made it much more difficult to conquer a town by force. Whereas in the past towns could be captured by assault, aggressors now had to encircle the town and starve it into submission. This move from quick assaults to lengthy sieges increased the size of the army needed for a successful attack: the size of armed forces in major European states increased tenfold 
between 1530 and $1710 .^{29}$ In summary, permanent armies, extensive training, standardised weaponry, new fortifications, and a larger number of soldiers fighting lengthier battles caused an increase in military expenditures. ${ }^{30}$ This had major implications for the public finance systems of the states involved in warfare.

This evolution was clearly at work during the Dutch Revolt. The Spanish army was highly professional and had a complex training scheme, whereby new recruits were not immediately sent to the frontline but spent up to two years in Italy or Northern Africa to learn combat discipline. ${ }^{31}$ Likewise, the Dutch mercenary army was transformed from an amalgam of mutinous soldiers with often conflicting interests to a professional and permanent, well-trained and disciplined force. ${ }^{32}$ 'The ordinary soldier [had become] "a salaried employee of the state rather than an adventurer" and "more amenable to programmatic training and discipline".,33

Both the Dutch and the Spanish invested heavily in improving the fortifications of their towns. ${ }^{34}$ This forced aggressors into protracted sieges throughout the Revolt. ${ }^{35}$ Such campaigns were costly. Already in 1574, still in the early years of the Revolt, the Spanish commander Requesens wrote that: "there would not be time or money enough in the world to reduce by force the 24 towns which have rebelled in Holland, if we are to spend as long in reducing each one of them as we have taken over similar ones so far. "36

\section{Spanish financing of the war}

Requesens' predictions proved to be correct. According to Drelichman and Voth who reconstructed government expenditures under Philip II, military outlays were by far the largest item in the Spanish budget. Between 1566 and 1596, total budget expenditures by Philip II amounted to 408 million florins, 
193 million of which were spent on the Dutch Revolt. ${ }^{37}$ In other words, about half of the Spanish budget was used to finance the war in the Low Countries during the reign of Philip II (1566 1596). 38

Table 1 shows estimates by Parker of the Spanish war budget in the Low Countries for selected years. According to Parker's calculations, between 1566 and 1648, the Spanish army in the Low Countries received at least 642 million florins from the crown, or on average 7.7 million florins per year.

Table 1 Spanish and Dutch War expenditures, in million

\begin{tabular}{|l|c|c|}
\hline Year & $\begin{array}{c}\text { Spanish } \\
\text { Army }\end{array}$ & $\begin{array}{c}\text { Dutch } \\
\text { Republic }\end{array}$ \\
\hline 1586 & 5.6 & 2.9 \\
\hline 1600 & 12.6 & 8.2 \\
\hline 1610 & 3.6 & 7.0 \\
\hline 1620 & 9.1 & 9.1 \\
\hline 1630 & 7.7 & 19.0 \\
\hline 1640 & 10.7 & 18.0 \\
\hline 1648 & 9.3 & 17.7 \\
\hline
\end{tabular}

Source: For the Dutch Republic, 't Hart ("De prijs van de vrijheid"). For the Spanish Army of Flanders: data from Parker (The Army of Flanders), Appendix K, p. 293. The Spanish expenditures for 1630 are an estimate based on interpolation. Spanish amounts were converted in pattards using Parker's annotations and then converted into florins at 20 pattards per florin (see the Appendix for a note on currencies).

To put this amount in perspective, compare these amounts with the revenues Spain obtained from silver and gold mined in the New World. After the discovery of important silver mines in its American colonies, a steady flow of silver found its way to Europe starting from the 1540s. The Spanish government allowed private entrepreneurs to mine the silver, but levied a $20 \%$ flat tax, which rapidly became an important source of revenue. By 1596, one fourth of the Spanish government budget was financed with silver taxes. ${ }^{39}$ Over the $1566-1648$ period, the tax revenues from 
the massive inflow of gold and silver from Spain's colonies in America were about 374 million florins (4.7 million florins per year). Hence, the cost of maintaining the Spanish troops in the Low Countries was more than $70 \%$ higher than revenues from the gold and silver inflows from the colonies. 40

Since the silver inflows from America were not sufficient, the Spanish empire repeatedly increased taxes in its heartland, the kingdom of Castile, in order to finance the war. ${ }^{41}$ Between 1591 and 1631, the per capita tax burden in Castile doubled. ${ }^{42}$ But even these efforts to increase tax revenues could not close the gap between expenditures and revenues. As a result, the Spanish government debt grew. ${ }^{43}$ The Dutch Revolt was such a large and permanent drain on the Spanish treasury that it inspired the Spanish expression poner una pica en Flandes ('to put a pike in Flanders'), which refers to starting a very costly and difficult undertaking. 44

Because of their difficulties in financing the war, the Spanish often built up large wage arrears. Throughout the Revolt, wage payments to the Spanish troops in the Low Countries were problematic. Troops often went unpaid for several months or even years. ${ }^{45}$ As a result, the Spanish army was plagued by widespread desertion and frequently paralysed by mutinies which undermined its military strength in the Low Countries. Mutinies 'became almost an institution of military life'. 46 The army witnessed at least 46 major mutinies between 1570 and 1607 , or on average more than one mutiny per year during this period. These mutinies were wellorganised, with soldiers electing their representatives to negotiate with the army leadership to make payments to the mutineers. 47

Mutinies had disastrous effects. One striking example concerns the siege of Zierikzee (1576) which was captured by the Spanish after nine months. However, after conquering the town, the soldiers 
discovered that the army could not pay their wages. A mutiny broke out and the Spanish soldiers left the city. ${ }^{48}$ In addition to abandoning their positions, mutineers could also turn to undisciplined looting. ${ }^{49}$ Mutinies also sabotaged major Spanish offensives in 1589, 1593 and 1600. A major mutiny in Diest (1607) undermined the Spanish bargaining position during the negotiations of the Twelve Years' Truce. In some cases, mutinous Spanish garrisons even sold their forts to the Dutch. 50

Hence, throughout the revolt, the Dutch dragged Spain into a long and costly war of attrition in which the financial capacities of the combatants eventually determined the outcome of the struggle.

\section{War finance in the Dutch Republic}

\subsection{The costs of war}

On the Dutch side, as on the Spanish, the costs of war were large. Annual war expenditures increased from 2.9 million florins in 1586 to 8.2 million florins in 1600. Even during the Twelve Years' Truce $(1609-1621)$ the war budget was between 7 and 9 million florins. Once fighting resumed, expenditures doubled to around 18 million florins annually until the end of the Revolt in 1648. War expenditures as a percentage of the GDP increased from $4.5 \%$ of the GDP in 1586 to around $8 \%$ in $1600 .{ }^{51}$ Even during the Twelve Years' Truce, Dutch war expenditure was around $6 \%$ of the GDP. Afterwards the financial burden of the war increased further to a peak of almost $12 \%$ of the GDP in 1630, decreasing toward $7 \%$ at the end of the Revolt. ${ }^{52}$

As the comparison of war expenditures for Spain and the Dutch Republic in Figure 3 shows, Dutch expenditures were considerably below Spanish expenditures during the first decades of the Revolt. In 1586 the Spanish spent 5.6 million florins on the war, compared to 2.9 million by the Dutch. The rebels had trouble financing the war during 
this early stage. In fact, one of the initial rebellions against the Spanish in 1568 failed because there was not enough money to pay the soldiers and 'the revolt ran out of money before it had really started'. 53 For some time, revenues came from a haphazard combination of piracy, support from foreign powers, confiscations of church property, debasements of the currency, and advances from army leaders. ${ }^{54}$ This system was unsatisfactory, and the rebels searched for a more systematic way of financing the war.

\section{Figure 3. Spanish and Dutch war expenditures, in million} florins.

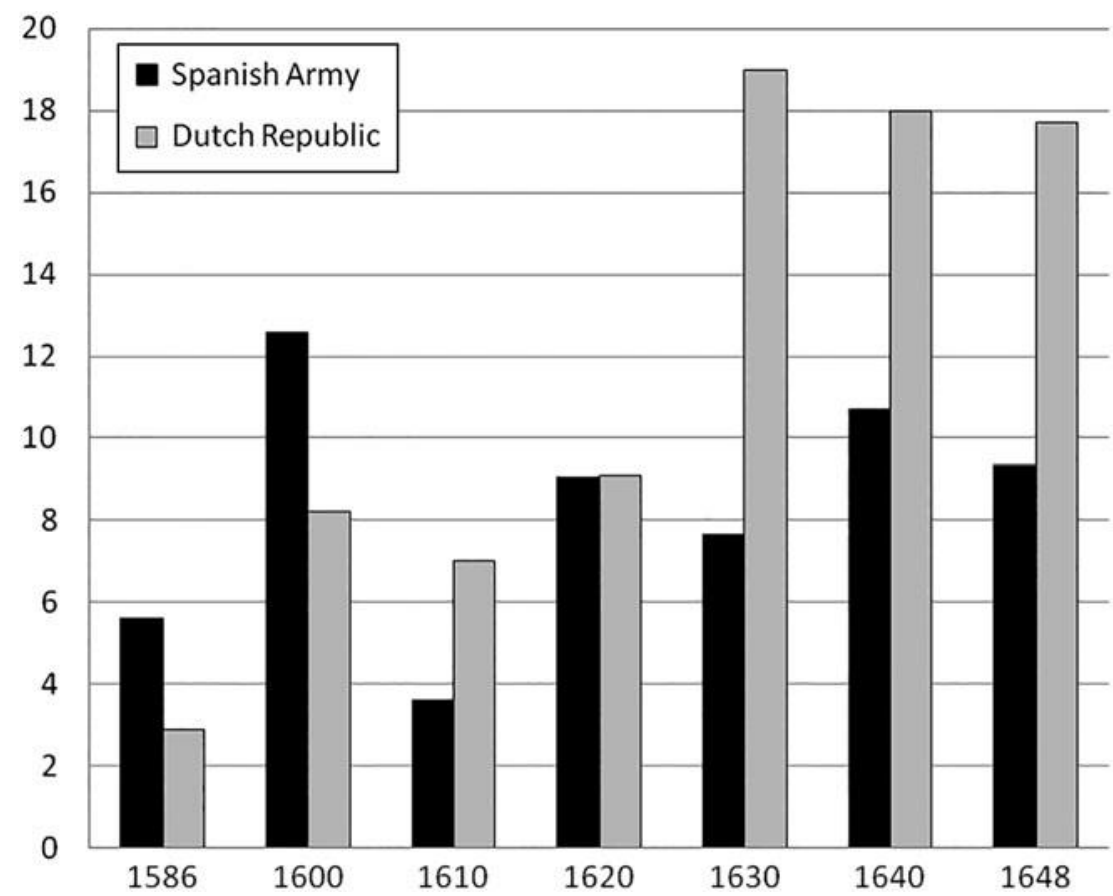

Source: see Table 1.

By developing an efficient system of taxation, the Dutch managed to increase their war budgets by $8.3 \%$ per year between 1586 and 1600 - one of the highest growth rates of war expenditures of all states in early modern Europe. ${ }^{55}$ As a result, after 1600, Dutch 
expenditures were considerably larger than the Spanish - almost double from the 1630 s onwards. ${ }^{56}$ Soldiers in the Dutch army were employed the year round and received a regularly paid wage, which played a major role in keeping up morale. As a result, the danger of mutinies under the Dutch army became scarce after 1590, as the Dutch managed to collect enough money to pay their soldiers regularly. 57 This gave the rebels an important military advantage, as regular pay to soldiers 'reinforced the discipline and professionalisation of Dutch military forces'. 58 With their troops regularly paid, the Dutch could 'wait for the predictable spells of Spanish exhaustion'.59 As noted by Parker 'It was the Dutch who first perfected techniques of war finance capable of sustaining an enormous army almost indefinitely., 60 Although Spain had a mighty empire and rich colonies, the Dutch developed a highly efficient system of public finance, which in the end allowed - them to outlast the Spanish: "The Dutch military, fiscal and political reforms of the late sixteenth century collectively constituted an outstanding development in military history, with far-reaching economic and social consequences for the northern Netherlands. "61

\subsection{Public finance in Holland}

The province of Holland, in particular, managed to increase its tax revenues dramatically to finance the Revolt. The financial performance of the Dutch Republic was inextricably linked to that of Holland since this province was the wealthiest, most populous and most powerful. As a result, in the quota system that was used to finance the central government's war budget, around $60 \%$ of the expenditures were assigned to Holland over the course of the Revolt (Table 2). ${ }^{62}$

Moreover, while some provinces paid their contributions late or not at all, Holland seems to have been most reliable. ${ }^{63}$ Overall, 
the trends in the revenues of the Dutch Republic as a whole broadly followed those of Holland. 64 To understand the success of war finance in the Dutch Republic, we must therefore study public finance in Holland.

Table 2. The share of each province in the essential provincial war expenditures (1575 - 1792, in per cent).

\begin{tabular}{|c|c|c|c|c|c|c|c|}
\hline & 1575 & 1585 & 1586 & 1595 & 1612 & 1616 & 1792 \\
\hline Gelderland & & & & & 5,50 & 5,61 & 6,04 \\
\hline Holland & 77.5 & 66,4 & 64,2 & 59.77 & 57.14 & 58,31 & 62,05 \\
\hline Zeeland & 22,5 & 13,6 & 15,8 & 14,71 & 11,00 & 9,18 & 3,80 \\
\hline Utrecht & & 6.65 & 6.65 & 6.18 & 5.71 & 5.83 & 4.50 \\
\hline Friesland & & 13,2 & 13,2 & 12.37 & 11.43 & 11.66 & 9.35 \\
\hline Overriisel & & & & & 3.50 & 3.57 & 3,48 \\
\hline Stad \& Lande & & & & 6.98 & 5.71 & 5.83 & 5.83 \\
\hline Drenthe & & & & & 1.00 & 1.00 & 0.99 \\
\hline Generality Lands & & & & & & & 4.41 \\
\hline Total & 100 & 100 & 100 & 100 & 100 & 100 & 100 \\
\hline
\end{tabular}

Source: Veenstra, Gewestelijke Financiën. Part VII: Zeeland, 15, 17.

Institutional reforms in the 1540s had given the province of Holland the possibility to raise province-wide taxes, as opposed to the system of fiscal autonomy of towns that existed before. ${ }^{65}$ Having a provincial tax administration made it possible to quickly introduce new taxes when war expenditures required an extra effort. As the Revolt continued, the province would repeatedly use this power to increase taxes. In this way, Holland secured a steady source of tax revenues which in turn enabled access to capital markets at relatively low interest rates.

A key feature of taxation in Holland was its reliance on excise taxes. Recent research on the composition of government finances in Holland allows us to estimate the importance of excises in total revenues. Figure 4 replicates the reconstruction by Fritschy (2003) of Holland's sources of funding between 1572 and 1648. During this period, Holland accounted for around $60 \%$ of total tax revenues of the Dutch Republic. This figure makes clear that credit, often cited as a major reason for Dutch success, only 
became important after 1620. Before that date, Holland financed the war overwhelmingly through taxes, mostly a real estate tax and, more importantly, the provincial excise taxes known as the 'common means' (see below). Both were levied for the first time in Holland following the tax reforms of the 1540s. The excise taxes were clearly the most important source of revenues. Over the entire period (1572-1648), the 'common means' made up more than half of total provincial revenues in Holland. Moreover, the real estate tax does not show any strong growth in revenues over time; almost the entire growth in tax revenue is due to the 'common means'. Excise taxes thus accounted for the bulk of government revenues in the province of Holland, a fact which surprised many contemporary observers. 66

The reconstruction of public expenditure in Holland between 1574 and 1652 shows that most of Hollands' public expenditure went to the war. ${ }^{67}$ The data also show that the burden on interest payments only grew after 1600 and especially 1621 (the end of the 'Twelve Years' Truce'). These data again confirm that 'given the high interest rates in the early decades of the Dutch Revolt, the part played by debt creation in financing the revolt must have been less than has been assumed' 68 
Figure 4. Components of revenue in Holland, in million florins.

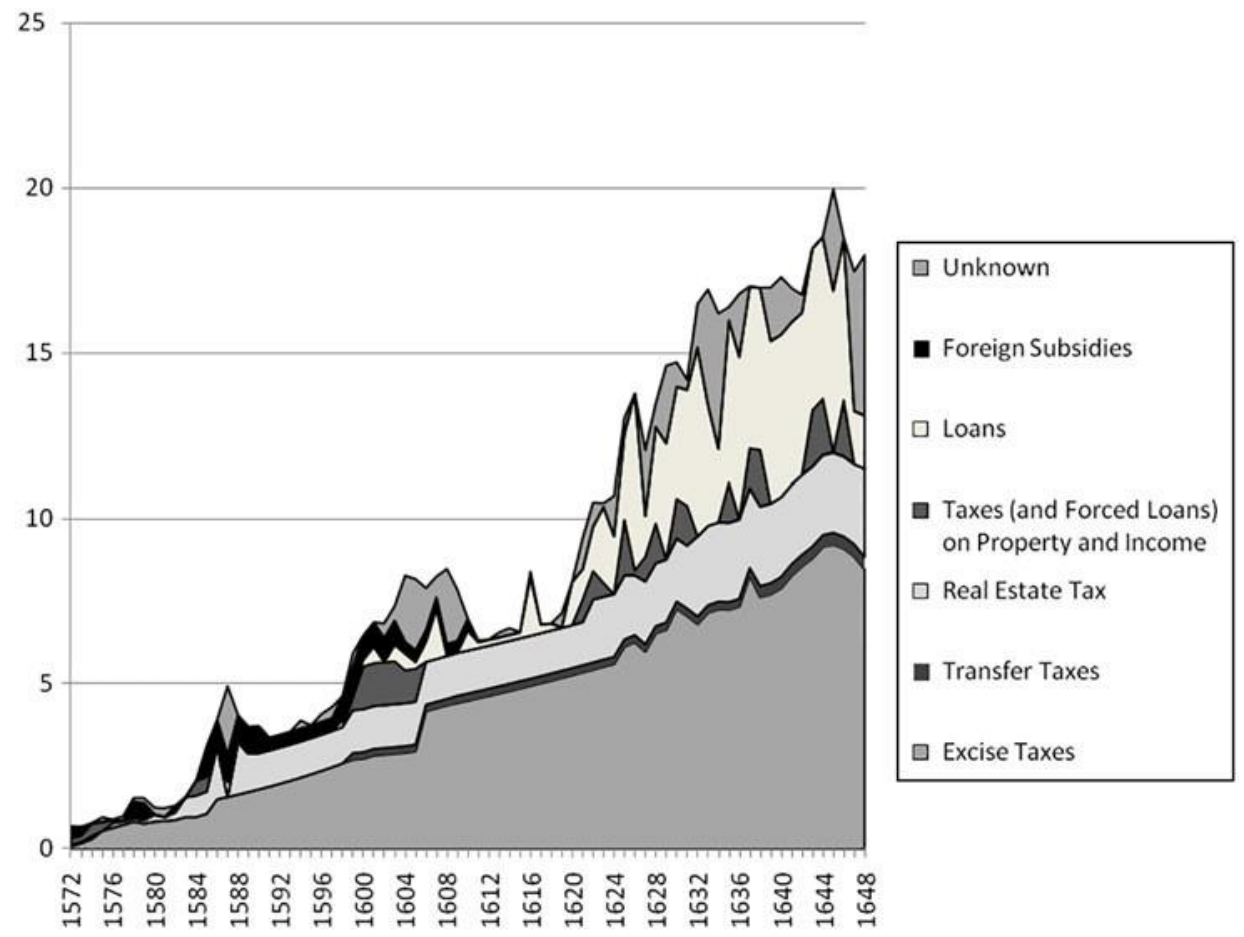

Source: Fritschy (“A Financial Revolution”), 66 and 83 - 85, and Liesker and Fritschy (Gewestelijke Financiën - Part IV: Holland), 160-163 and 206-207.

\section{The share of beer taxes}

Analysing Holland's tax revenues in more detail shows the importance of beer taxes during the Dutch Revolt. In 1572, Holland was the first province to financially support the revolt against Spain. The province decided that the revenue of different excise taxes would be used for this purpose. By 1572, some $40 \%$ of total provincial tax revenues of Holland came from the excise on beer and wine; beer was probably responsible for three quarters of this. ${ }^{69}$ However, the revenues were insufficient to finance the war effort. Therefore, in 1573, Holland doubled the tax on beer and wine while suspending all other excises, but the demands of war 
kept outpacing revenues. ${ }^{70}$ In 1574 , the town deputies who made up the representative assembly of Holland took a drastic step. They decided that cities would only be entitled to keep one-third of their urban beer and wine excises, the main source of revenues for the towns. The remaining two-thirds were taken by the province, which added the money to the revenues from its own provincial beer and wine excises. This was an unprecedented appropriation of city revenues by the provincial government and one that was not universally accepted: the towns in North Holland insisted on keeping half of their excise revenue. This demand was granted to them, provided they used the money for fortifications. 71

Later that year, Holland realised that it could not pay the promised amount of money, and it took a second important decision. The province introduced a series of new excise taxes known as the 'common means' (gemene middelen) on products such as wine, beer, milled grain, peat, slaughtered cattle, soap and fish. 72 Initially, Holland did not use these taxes to finance its share in the costs of the war, but rather to be able to pay the interest payments on loans that were taken on the region as a whole (i.e. on the 'common land'). In 1576, in the Union of Delft, the province of Zeeland agreed to impose this new provincial excise tax as well. Moreover, it was decided that from that moment onwards these 'common means' would be solely used to finance the war. ${ }^{73}$ In 1579 , in the Union of Utrecht, five other regions joined the coalition; again, it was agreed that the war would be financed by the 'common means'. Moreover, the Union stated that these common means were only aimed at financing the war, 'without the permission to use these means for anything else'. 74

The available evidence indicates that beer excise taxes were the single most important element of these common means (Table 3). In 1575 the beer and wine excise jointly accounted for $44 \%$ of excise tax revenues. Assuming beer accounted for three quarters, this puts the contribution of the beer excise in total excise tax 
revenues at $33 \%$ in 1575 . In 1590 the taxes on beer amounted to some 490.000 florins on estimated total excise revenues of 1.8 million florins, or $28 \%$. In 1608 , at the eve of the Twelve Years' Truce, taxes on beer accounted for 1.5 million florins on total excise revenues of 4.3 million florins, or $35 \% .^{75}$ In 1650 , shortly after the Revolt had ended, the share of beer was $29 \% .^{76}$ Taking a simple average of these estimates, the beer excise seems to have accounted for around $31 \%$ of total excise revenues across Holland, a proportion which was remarkably stable throughout the Revolt (Table 3). Combining this information with data on the importance of excises in total revenues allows us to estimate the net contribution of beer taxes. Over the entire period of the Dutch Revolt, the 'common means' accounted for $56 \%$ of revenues (see Table 4). This share was usually above $50 \%$ and in some years even reached $70 \%$. Between 1572 and 1620, 'common means' accounted for $64 \%$ of revenues; between 1621 and 1648, when Holland increasingly used loans to finance expenditure, this share decreased to $52 \%$.

Table 3. Share of the beer excise in total excise revenues in Holland

\begin{tabular}{|l|c|}
\hline Year & Share of the beer excise \\
\hline 1575 & $33.0 \%^{\mathrm{b}}$ \\
\hline 1590 & $27.5 \%$ \\
\hline 1608 & $35.4 \%$ \\
\hline 1650 & $28.9 \%$ \\
\hline $1575-1648$ & $31.2 \% \mathrm{c}$ \\
\hline 1668 & $21.6 \%$ \\
\hline 1680 & $15.9 \%$ \\
\hline
\end{tabular}

Note: 'The beer excise consists of 'bieren' and 'stuivers op tonnebier' for 1575, 1590 and 1608; and 'bieren', 'stuivers op bier voor de renten', 'stuivers op de bieren', 'binnenbieren' and 'buitenbieren' after 1608; 'b Assuming beer accounted for threequarters of joint excise on beer and wine; ${ }^{\mathrm{c}}$ Calculated as unweighted average of the shares for the four available years.

Sources: The share of the beer excise in Holland was calculated from Liesker and Fritschy, Gewestelijke Financiën. Part IV: Holland, 160 and 165 (for 1575); 160 
and 169 (for 1590); 246 and 259 (for 1608); 162 and 246 (for 1650); 238 and 246 (for 1668); 238 and 246 (for 1680).

Table 4. Share of the excises (common means) in total revenues in Holland (1572 -1648).

\begin{tabular}{|c|c|c|}
\hline Period & $\begin{array}{c}\text { Excises(Common } \\
\text { Means) as of Total } \\
\text { Revenues }\end{array}$ & $\begin{array}{c}\text { Implied \% of Beer } \\
\text { Excise in Total } \\
\text { Revenues }\end{array}$ \\
\hline $1572-1580$ & 71 & 22 \\
\hline $1581-1590$ & 58 & 18 \\
\hline $1591-1600$ & 62 & 19 \\
\hline $1601-1610$ & 59 & 18 \\
\hline $1611-1620$ & 71 & 22 \\
\hline $1621-1630$ & 53 & 17 \\
\hline $1631-1640$ & 49 & 15 \\
\hline $1641-1650$ & 56 & 18 \\
\hline $1572-1648$ & 56 & 18 \\
\hline $1572-1620$ & 64 & 16 \\
\hline $1621-1648$ & 52 & 20 \\
\hline
\end{tabular}

Sources: Share of 'common means' in total revenues calculated from Fritschy, "A Financial Revolution," 85; Liesker and Fritschy, Gewestelijke Financiën. Part IV: Holland, 154-155 and 160-164. The implied share of the beer excise is obtained by assuming the beer excise accounted for $31 \%$ of the common means (see Table 3).

Using our estimate that beer was responsible for about $31 \%$ of this total, beer excises thus probably accounted for $15 \%$ to $22 \%$ of total revenues in Holland, or around $18 \%$ over the course of the Revolt. Not only was beer the single largest component of the 'common means', the share of beer in total revenues also seems to have been about as great as that of the real estate tax (which also accounts for $18 \%$ of total revenues during the Revolt). Hence, beer taxes were one of the largest revenue sources of the province of Holland during the Revolt. ${ }^{77}$

Moreover, while the real estate tax was important, total revenues from this tax did not increase strongly throughout the Revolt. By contrast, whenever more revenue was needed, the tax on beer increased. ${ }^{78}$ Table 5 presents provincial tax rates for beer sold in pubs for the years 1582, 1605 and 1655 (shortly after the 
end of the Revolt). In 1582, the provincial tax rate on cheap beer was at least $20 \%$, rising to more than $100 \%$ for more expensive domestic beers. Foreign beers were taxed even more. ${ }^{79}$ In 1605 , the tax on cheap beer had increased to at least 30\%. Beers of more than 40 stuivers per tun had to pay 73 stuivers in excises, which meant the tax rate was around $180 \%$ for beers costing over 40 stuivers. On top of these taxes for beer sold in pubs, the province also levied a tax on beer in general (the gijlimpost), which was 2 stuivers per tun, at least from 1584 onwards. ${ }^{80}$ Moreover, apart from these provincial taxes, towns could add extra excises of their own. For instance, in 1582 towns could add an extra 8 stuivers to the excise on beer priced between 30 and 40 stuivers; this meant the tax rate in this category could already in 1582 be as high as $80 \% .{ }^{81}$ Beer was obviously an attractive source of revenue for authorities at all levels of government, and tax rates on beer reached very high levels as a result.

To appreciate the importance of taxes on beer in the context of the Spanish-Dutch conflict, it is instructive to contrast the size of the Spanish silver revenues from America with the Dutch revenues from taxes on beer. Figure 5 compares the evolution of Spanish silver tax revenues with the revenues from taxes on beer in Holland. Spanish silver revenues peaked during the last decade of the sixteenth century but remained important throughout the Dutch Revolt. Holland's beer tax revenue increased during the Revolt. We estimate that over the entire course of the war, beer taxes in Holland alone amounted to $29 \%$ of the entire Spanish silver tax revenues. ${ }^{82}$ Whereas these beer taxes only amounted to some $6 \%$ of Spanish silver tax revenues during the first decade of the Revolt, they increased to $32 \%$ during the Twelve Years' Truce (1612 - 1621), and to half of Spanish silver tax revenues during the 1630s. During the final years of the Revolt, the beer tax in Holland brought in as much revenues as the Spanish silver tax. 83 
Table 5. Provincial excises on beer in Holland, in stuivers per tun.

\begin{tabular}{|c|c|c|c|c|c|c|}
\hline & \multicolumn{2}{|c|}{1582} & \multicolumn{2}{|c|}{1605} & \multicolumn{2}{|c|}{1655} \\
\hline Type of beer & Tax & Rate* & Tax & Rate* & Tax & Rate* \\
\hline Priced less than 20 stuivers per tun & 4 st. & $20 \%$ & 6 & $30 \%$ & 11 & $55 \%$ \\
\hline Priced between 20 and 30 st. & 10 & $40 \%$ & 22 & $88 \%$ & 22 & $88 \%$ \\
\hline Priced between 30 and 40 st. & 16 & $45 \%$ & 30 & $85 \%$ & 30 & $85 \%$ \\
\hline Priced more than 40 st. & 42 & $105 \%$ & 73 & $183 \%$ & 73 & $183 \%$ \\
\hline Joopen-beer & 360 & & 585 & & 645 & \\
\hline Beer from England, Lübeck, & 60 & & 110 & & 140 & \\
\hline Eastern beer & 50 & & 93 & & n.a. & \\
\hline
\end{tabular}

Notes: *Columns labelled 'rate' give an estimate of the tax rate expressed as a value-added tax. The rate is calculated for beer priced 20st., 25st., 35st. and 40st. respectively. One florin consisted of 20 stuivers.

Source: Unger, Brewing in Holland, 317.

Figure 5. Spanish Silver versus Dutch Beer, in million florins.

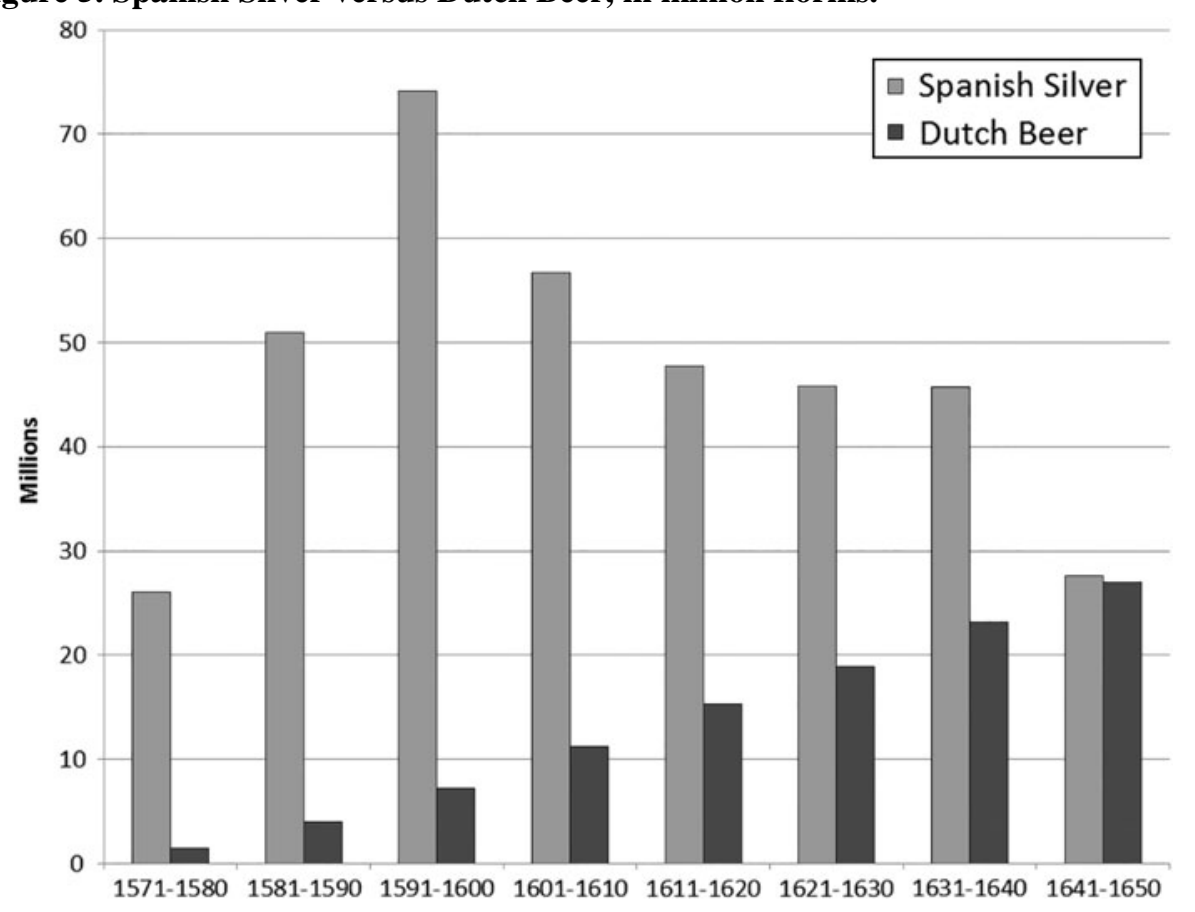

Source: Data on Spanish silver from Gelabert ("Castile, 1504 - 1808”), converted into florins using the procedure outlined in the appendix. Data on Dutch beer taxes are authors' calculations based on Fritschy, "A Financial Revolution," 85 and 
Liesker and Fritschy, Gewestelijke Financiën. Part IV: Holland, 154 - 155, 160 $165,168-169,238,246$ and 259.

\section{Why beer taxes?}

As the previous section documented, beer was of crucial importance to government finances in Holland during the Dutch Revolt. Two factors explain the paramount importance of beer in financing the Dutch Revolt. First, in early modern times, beer played a central role in daily consumption patterns. Second, the towns of Holland had developed a very effective system of collecting the beer excise. In this section, we discuss the importance of beer and beer taxes and the enforcement of the beer tax. We also compare the beer tax to the bread tax, another important revenue source.

\subsection{The importance of beer}

The role of beer in daily life during the Middle Ages and the Renaissance can hardly be exaggerated. To most people, beer was a necessity and an important part of their diets: 'a beverage for all times of the day from breakfast to dinner and into the evening, 84 Other beverages were often less attractive: water could be polluted and unhealthy, milk was perishable, tea and coffee were only introduced in later centuries, and wine was too expensive for most people. ${ }^{85}$ By contrast, beer was relatively nutritious, healthy and cheap. Moreover, after the introduction of hopped beers, it could be kept longer than most other beverages. Furthermore, beer was the least expensive 'provider of calories' of all available drinks. ${ }^{86}$ The Low Countries in particular had a reputation for drinking vast quantities of beer. ${ }^{87}$ A per capita consumption of one litre per day for Dutch towns seems to be a reasonable estimate, with estimates of yearly consumption in the Netherlands ranging between 200 and 
400 litres per capita. ${ }^{88}$ This is much higher than current per capita consumption levels, which are around 80 litres per capita for the Netherlands and around 100 liters per capita for Belgium. ${ }^{89}$ The high demand for beer explains the prominence of the brewing industry in the economy of medieval and early modern towns. 90 Many towns had brewers specialising in higher quality beers for export to other towns and regions. This production for export made beer into one of the pillars of the economy in Holland, comparable with the more famous textile industries. ${ }^{91}$

\subsection{Taxation of beer}

Not surprisingly, the importance of beer in daily life, and the fact that demand was inelastic given the lack of substitutes, drew the attention of rulers in search of tax revenues. ${ }^{92}$ As early as the ninth century, a widely used additive to beer called gruit was the subject of regulation and taxation efforts by rulers. ${ }^{93}$ The tax on gruit was eventually transformed into a general tax on beer of any type, levied by the towns. In many of the major towns in the Low Countries, this beer excise became the most important source of income, often accounting for more than $50 \%$ of total tax revenue in the fifteenth and sixteenth century. ${ }^{94}$ As early as the fourteenth century, cities in the Netherlands sold bonds secured specifically by this beer tax revenue. In short, 'municipal finance. floated as a cork on a great pool of beer'. 95

Over time, beer became subject to a number of different taxes. Different excise taxes were due on different types of beer, depending on the additives used, the color of the beer, its strength, its provenance, and so on. For instance, so-called 'scharbier', or 'thin beer' (very low quality beer made from the last mashing) was free from taxation, and taxes on beer produced within the city walls were lower than those for imported beers. Tax exemptions or a decrease in taxes existed for 
specific circumstances. For instance, sailors could buy beer at a lower rate prior to sailing off, to ensure that they bought beer from local producers instead of consuming beer at ports they visited. 96

In addition to the beer excise, there was a tax on the production of beer known as the gijlimpost. This tax was fixed at 2 stuivers per tun during the Revolt and had to be paid when the barrels were filled, which required in turn that agents of the tax collector were present whenever beer went into the barrels. There were also taxes on the grain and fuel used by brewers, on the grinding of the grain, on the weighing of raw materials, and a host of other levies whenever the brewer exported the beer. ${ }^{97}$ However, shortly after the Revolt, the governments of Holland and Zeeland abandoned this complicated system in favor of a much easier system of tax brackets based on the wholesale price of the beer, with a higher amount of excises due for higher-priced beer. ${ }^{98}$

\subsection{Enforcement of the beer tax}

Fraud was commonplace as brewers tried to circumvent the beer taxes by all means. The local governments, in turn, were inventive in imposing new rules and taxes. Home brewing, for instance, was in principle subject to taxation although this was difficult to enforce. Towns tried to tax home brewing by several means, for instance at a fixed rate per brew. However, as it was difficult to collect these taxes, the government of Holland, following an earlier move by the town of Amsterdam, simply outlawed home brewing in the entire province in 1580.99

A similar approach was used to battle the problem of breweries and taverns outside town walls, which did not pay urban excises. As beer from the countryside was not taxed, citizens left the city to taste a beer outside the city walls at lower prices. This phenomenon was labeled as 'buitendrinken' (drinking outside the city walls). 100 Brewers also tried to get their beers that were produced outside the 
city walls into the city without paying any tax. This problem of drinking and/or producing beer outside the city walls became even bigger when, over time, rural brewers learned to make better brews that became real competitors for the better quality urban brews by offering "a less expensive alternative"101. In 1525, several towns petitioned the government of the province of Holland and offered a payment of 100,000 pounds in exchange for prohibiting all brewing in the countryside. Eventually, in 1531, the government agreed and issued a set of regulations on rural industry, including restrictions on brewing and selling beer outside towns, amongst which were the prohibition of any new breweries in the countryside and the permission only of taverns that were located at least at six kilometres from the city walls or that only sold inferior beer. 102

A third example of tax evasion was misrepresenting the beer that was brewed and sold. A large variety of different names were used for different types of beer, 'often in the hope that some tax burden might be reduced because of confusion among tax collectors.' 103 Since scientific methods of assessment, e.g. the alcohol percentage of beer, would only be developed in later centuries, towns usually had strict rules defining the different types of beer and their production process, to avoid brewers claiming that their beer belonged in a less heavily taxed category. If brewers wanted to brew different types of beer, they first had to store the output left of the previous brew in the cellar of a house on the opposite side of the street until the entire output was sold, to make sure that both brews could not be mixed up. In this way, brewers could not state they had made a mistake when they were caught trying to get the better beer taxed as a lower quality beer. ${ }^{104}$ Rules on brewing also typically specified what types of ingredients the brewer could use for what type of beer and in what quantities; the maximum size of the brewing kettle; the maximum frequency of brewing; and the times of day during which brewing was allowed. ${ }^{105}$ In addition, 
the price of beer was fixed by regulations. After the Revolt, as the provinces of Holland and Zeeland switched to a less complicated tax system, there was a widespread deregulation of the brewing industry, which suggests that quality regulation in brewing was mostly aimed at preventing tax evasion and had become unnecessary with the new, easier system. 106

Most cities in the Netherlands developed a similar system during the sixteenth century to minimise the possibility of fraud and tax evasion based on a strict separation of beer production, beer transportation and beer selling. In practically every town, only officially licensed and sworn beer porters were allowed to transport beer. No barrel of beer could leave the brewery unless there was a receipt to prove that all necessary excises had been paid. Porters were forbidden from delivering beer unless there was a receipt, and it was their task to hand over the receipt to the buyer. Anyone who sold beer (e.g. in a tavern)needed receipts to prove that all taxes had been paid. The beer porters were de facto agents of the tax collector, with strict rules on their duties and rights. In Amsterdam, for instance, beer porters could not work on holidays, could not refuse work, and earned a fixed wage controlled by the town government. Moreover, porters were prohibited from selling beer themselves. Governments were also concerned about other possibilities for tax evasion (apart from the ones already mentioned above). Ship builders, for instance, could traditionally buy beer tax free. To avoid evasion, the town of Amsterdam decreed that they would have to pay the taxes first, and then ask a rebate afterwards. 107

High taxes on beer occasionally led to tax revolts, which could delay the increase or the imposition of new beer taxes for some time. For instance, in 1616, there was a violent revolt in Delft. ${ }^{108}$ Tax collectors (usually private agents who bought the right to collect the taxes from the town government) were not well-liked and often the victim of aggression. For this reason, they could ask 
for protection and help from the town officials when doing their rounds. As the money was badly needed for the war against Spain, however, the town representatives experimented with the type and form of the taxes to make tax revolts less likely. For instance, taxes that were levied on each brew were less visible for consumers than taxes levied on each barrel. 109

The success of the beer excise was thus due in large part to the highly efficient system of tax enforcement that was improved over time by adding and modifying legislation, or as Unger put it: 'Each new regulation was presumably designed to stamp out some novel form of tax evasion'. ${ }^{110}$ In 1616 , legislation on beer was codified for the entire Dutch Republic stating the standard requirements brewers needed to follow: “... to use sworn beer porters, to use excise tickets, to tell the excise man about any beer to be exported, to follow accepted accounting procedures and for brewers as well as wholesalers and beer porters not to sell at retail." 111

\subsection{Comparison with the Bread Tax}

The success of beer taxes can thus be understood as the combined effect of the enormous popularity of beer on the one hand and a highly developed system for tax enforcement on the other hand. The notoriously high levels of beer consumption and the system with tax receipts and official beer porters acting as agents of the tax collector guaranteed a large and steady flow of revenues.

Beer was not the only commodity with these characteristics, however. Another good with high consumption levels and a highly efficient system of taxation was bread. Like beer, bread was an essential part of the daily diet. ${ }^{112}$ Bread was consumed daily and often represented the largest category of expenditure for households, as well as the largest source of calories. Alternatives such as the potato were only introduced in the eighteenth 
century. ${ }^{113}$ Most of the literature on taxes in Holland during the sixteenth and seventeenth centuries focuses on the bread tax, with little or no attention to the tax on beer (e.g. the work of Jan De Vries). ${ }^{114}$ It is therefore interesting to compare the taxation of both commodities.

As with beer, the system for collecting the bread tax was highly efficient. The main tax on bread was in fact a milling tax on grain known as 't gemaal' and collected at the grain mills. 115 As with the beer excise, which was collected at the brewery and not at the pub, this probably facilitated tax collection. The milling tax varied according to the type of grain and the use of the grain. Bread production was subject to price regulation, which limited the scope for bakers to pass on the costs of the tax to consumers. 116 To balance the objectives of maximum tax revenues, an acceptable income for bakers, and affordable bread for consumers, tax authorities often engaged in public experiments to find out how much grain and how many other inputs were needed to bake a loaf of bread. These cost estimates were then used to set the tax rates on grain. 117

The milling tax also showed an increase throughout the Revolt. In 1574, the milling tax on wheat was 3 guilders per last (a unit of volume). The tax doubled in 1583 and again in 1597 and would continue to increase. By 1636 the tax rate was 31.8 guilders, or more than ten times the rate at the start of the Revolt. ${ }^{118}$ As a result, the share of the milling tax in the 'common means' increased over time, from around 4\% in 1575 and 1590 to $16 \%$ in 1608 and $21 \%$ in $1650 .{ }^{119}$ The milling tax thus brought in considerably less than the beer excise, which accounted for around $31 \%$ of the 'common means' throughout the Revolt (see above) whereas the milling tax brought in around $12 \% .{ }^{120}$ In terms of its total contribution to war finance during the Revolt, bread was therefore 
clearly less important than beer. However, the importance of the milling tax increased over time, while the beer excise started to decline after the Revolt. By 1668, 20 years after the Revolt, the beer excise and the milling tax both brought in around $22 \%$ of the 'common means'. By 1680, the beer excise had shrunk to $16 \%$,

while the milling tax brought in around 24\%. ${ }^{121}$ This decline in the beer excise mimics the long-term decrease in beer consumption which started in the second half of the seventeenth century. ${ }^{122}$ After the end of the Revolt, the milling tax thus gradually replaced the beer excise in terms of importance.

\subsection{Spain and the Beer Tax}

As beer consumption was large throughout the Low Countries, and towns in the Spanish- occupied Low Countries had as much experience with taxing beer as those in the Dutch Republic one may wonder why the Spanish did not use local taxes in the occupied Netherlands as was the case in the Northern part. The answer probably lies in the differing institutional environments facing the Spanish government in the southern Low Countries and the provincial government of Holland. Following institutional reforms in the 1540s, the province of Holland had obtained the right to levy province-wide taxes, overruling the traditional privileges of urban autonomy in taxation (see above). It was this provincial taxation power which made it possible to quickly raise funds through higher taxes whenever the demands of war required it.

In the Spanish Low Countries, the Spanish did not have such a degree of fiscal efficiency. Whenever the Spanish government in Brussels wanted to raise more funds, it had to engage in a long negotiation process with representatives of the different provinces and towns which insisted on their traditional privileges. Moreover, the central government in Brussels had little institutional capacity and was forced to rely on local governments for tax collection. ${ }^{123}$ 
Resistance to tax increases was strong and prevented the Spanish from extracting more funds locally.

For example, the Duke of Alva, who had been sent by the Spanish king to restore order in the Low Countries, received the message that the cost of maintaining his troops was weighing too heavily on the Spanish treasury and that it was necessary to raise taxes in the Low Countries. ${ }^{124}$ Alva's subsequent attempt to impose new taxes in 1571, overruling traditional privileges, was the spark that re-ignited the Dutch Revolt. As a result, the Spanish government in Brussels never managed to extract any significant amount of revenues from the Low Countries, but had to rely on transfers from Spain throughout the Revolt. ${ }^{125}$ Because of these institutional obstacles, the Spanish were unable to tap into the same income sources which financed the Dutch rebels.

The Spanish king faced similar constraints at home. Taxes in sixteenth century Spain had to be approved by the representatives of the town in the Cortes, Castile's parliament. Apart from direct taxes (servicios), there were also sales taxes (alcabalas), as well as a few additional income streams. The alcabala sales tax (the most important source of Crown revenue) was payable by everybody regardless of social status, and was officially set at $10 \%$ of every transaction in the kingdom of Castile. However, this was nearly impossible to administer: 'For an early modern economy, it would have been both extremely onerous and impractical to collect'. ${ }^{126}$ Instead, each year a lump sum payment was negotiated between the king and the representatives of the towns in the Cortes. The Cortes divided the amount due between the different cities by means of a quota, and each city could decide on its own how it wanted to collect the money. For instance, some cities only taxed goods that were easy to monitor, such as goods that were sold through licensed establishments. Other cities reverted to a tax farm or direct collection to collect the money. Throughout the sixteenth century, the alcabala tax became the most important revenue of the royal income, accounting for up to one third 
of the total. As the alcabala grew in importance, the bargaining power of the Cortes increased. In 1573, the king requested a tripling of the total tax payment. The Cortes refused, and the king threatened to implement the official tax rate of $10 \%$ instead. Realizing that the king did not have the institutional capacity for this, however, the Cortes called his bluff. The negotiations dragged on for two years and were only resolved temporarily in the face of a looming default of the Spanish Crown (Drelichman, 2013). In addition to this institutional constraint, over time the citizens of Castile were increasingly less inclined to pay for a faraway war from which they did not derive any economic benefit. ${ }^{127}$ In contrast with the Dutch Republic, warfare 'did not advance Spanish state formation but rather contributed to the weakening of the government'. 128

\section{Conclusion}

In the final decades of the sixteenth century, unrest in the Low Countries turned into a fully- fledged revolution against Spanish rule. Initially, this Revolt seemed a hopeless case, with just a handful of towns struggling against the mightiest empire on earth. However, after 80 years of fighting, an exhausted Spanish Empire was prepared to sign the 1648 Treaty of Münster, giving the rebels independence on extremely favorable terms. The Treaty divided the Low Countries into the Dutch Republic in the north and Spanishoccupied territories in the south. This border, drawn in 1648, still separates Belgium and the Netherlands.

Instead of winning a quick victory against the rebels, Spain got dragged into one of the longest uprisings of European history. The conflict escalated into a war of attrition, with ever-increasing costs, which put an enormous pressure on the public finance systems of both Spain and the Dutch Republic. Taxes on the large silver inflows from the Spanish colonies in America only covered about half of the costs of war, and Spain constantly struggled to finance its 
military expenditures. As a result, Spanish soldiers went unpaid for months, and discontent and mutiny paralyzed the Spanish army in the Low Countries. The Dutch, by contrast, developed a highly efficient public finance system which allowed it to raise unprecedented amounts of tax revenue. This stable source of revenues gave the Dutch the means to finance the increasing costs of war while providing a regular pay to their soldiers.

In this article, we have documented the contribution of beer to financing the Dutch struggle for independence from Spain. Throughout the Revolt, taxes on beer accounted for $15 \%$ to $22 \%$ of total revenues in Holland, the leading province of the Dutch Republic, making it one of the largest sources of revenue during the Revolt. A comparison with Spanish silver taxes demonstrates that beer taxes in Holland alone brought in the equivalent of $29 \%$ of the Spanish silver taxes during the Revolt. During the last decade of the Revolt, Dutch beer taxes brought in as much revenue as the tax on silver from the Spanish colonies.

The surprisingly large contribution of beer taxes can be explained by the combination of the importance of beer in daily consumption patterns in early modern times and the efficient beer tax enforcement. The large and steady flow of fiscal revenues from beer taxes played an important role in allowing the Dutch Republic to break away from Spanish rule, leaving the territory of presentday Belgium behind as the remainder of the Spanish Low Countries. The border established by this separation, although initially arbitrary, still largely forms the division between Belgium and the Netherlands. In this way, beer contributed to the separation of the Low Countries, the creation of Belgium, and the present-day border between Belgium and the Netherlands.

\section{Acknowledgements}

The authors wish to thank Erik Aerts, Carlos Alvarez-Nogal, Mauricio Drelichman, Florike Egmond, Jose Ignacio Andres 
Ucendo, Erik Schokkaert, Marjolein 't Hart, Richard Unger, Thijs Vandemoortele, Hanneke van der Eerden, Joris Wauters, Steve Ziliak, and seminar participants at LICOS (KU Leuven), the $6^{\text {th }}$ Annual Meeting of the American Association of Wine Economists (Princeton, NJ, June 2012), and the Third Beeronomics Conference (York, UK, September 2013). Special thanks to Giulia Meloni for stimulating discussions which greatly improved the article. All remaining errors are our own.

\section{Funding}

This work was supported by a Methusalem Grant of the Research Fund of the University of Leuven (KU Leuven).

\section{$\underline{\text { Notes }}$}

1. Acemoglu, Johnson, and Robinson, 2005, "Institutions as a Fundamental Cause"; North, "Institutions."

2. Bockstette, Chanda, and Putterman, 2002, "States and Markets"; Hanson, "Forging Then Taming."

3. Tilly, Coercion, Capital.

4. The term 'Low Countries' refers to the territory occupied by present-day Belgium and the Netherlands. To avoid confusion, throughout this paper we use the term 'Netherlands' only to describe the territory presently occupied by this country. Thus, whenever we refer to Spanish- occupied territory in the Low Countries we will use the term 'Spanish Low Countries' instead of the more common term 'Spanish Netherlands'.

5. We draw upon several important contributions on the Dutch Revolt and the (founding of the) Dutch Republic by: Parker, The Dutch Revolt and Spain and The Netherlands; Israel, The Dutch Republic; Blom and Lamberts, Geschiedenis van de Nederlanden; Tracy, The Founding; Gelderblom, The Political Economy of the Dutch Republic ; 't Hart, The Dutch Wars. For recent scholarship on the economy of Holland, see Van Bavel and Van Zanden, "The Jump-start"; Van Leeuwen and Van Zanden, "Persistent but not Consistent."

6. Important contributions on the public finances in Holland include Tracy, "The Taxation System"; 't Hart, "Staatsvorming", The Making, "De democratische paradox" and The Dutch Wars; 't Hart, Jonker, and van Zanden, A Financial History; Fritschy, "A 'Financial Revolution"' and Fritschy, "The Efficiency"; Tracy, "Holland's New Fiscal Regime"; Gelderblom and Jonker, "Public Finance." Our analysis uses data collected as part of the Gewestelijke Financiën project coordinated by Wantje Fritschy, which reconstructed public finances for the seven provinces of the Dutch Republic: Fritschy, Gewestelijke Financiën - Part I: Overijssel; Van der Ent and Fritschy, 
Gewestelijke Financiën - Part II: Drenthe; Van der Ent and Enthoven, Gewestelijke Financiën - Part III: Groningen; Liesker and Fritschy, Gewestelijke Financiën - Part IV: Holland; Verstegen, Gewestelijke Financiën - Part V: Utrecht; Trompetter, Gewestelijke Financiën - Part VI: Friesland; Veenstra, Gewestelijke Financiën - Part VII: Zeeland. For Spanish public finance, we draw upon Gelabert, "Castile, 1504- 1808"; Drelichman and Voth, "The Sustainable Debts"; Drelichman, "European State Finance."

7. We draw upon contributions by Yntema, The Brewing Industry and "Een kapitale nering"; Unger, A History of Brewing and Beer in the MiddleAges.

8. Nye shows how during the Anglo-French wars at the end of the seventeenth century the British imposed high tariffs on French wine, thereby stimulating the rise of a domestic brewing industry. By encouraging oligopoly, government regulations created rents in the industry, which it could subsequently tax. The beer taxes contributed strongly to an increase in tax revenues which the British state used to finance its imperial expansion and which eventually made Britain the dominant military power in the world. Nye, War, Wine and Taxes and "Brewing Nation."

9. Van Deursen, "De Republiek," 147-148.

10. For an overview of the military events during the Dutch Revolt and the decade thereafter, we refer to 't Hart, "Military Events." For other accounts of the Dutch Revolt, see endnote 5.

11. The fighting was interrupted by the Twelve Years Truce (1609-1621). The Dutch Revolt is also known as the Eighty Years' War, taking as a starting point the Battle of Heiligerlee in 1568. However, this choice of starting point is mostly inspired by the fact that it leads to exactly eighty years of conflict. Various other events could equally be chosen as the starting point of the Revolt, such as the Iconoclastic Fury of 1566 or the capture of the town of Den Briel by the rebels in 1572 .

12. Israel, The Dutch Republic, 596; Van Deursen, "De Republiek," 147-148.

13. During the Iconoclastic Fury of 1566, for instance, iconoclasm - the destruction of religious images, symbols and statues - was most widespread in the south of Flanders and around Antwerp, from which it then spread to towns in the north (see the map in Parker, The Dutch Revolt,77).

14. Van Ham, "Ontstaan door strijd," 8-9, 14, 21, 28-29.

15. This created an interesting political situation. The Dutch Republic was essentially a union of autonomous provinces, represented in national politics by delegates from the traditional provincial governments. However, since the Dutch-occupied parts of Brabant and Flanders were cut off from their provincial government, they could not send any delegates. As a result, these regions were put directly under the control of the federal government as 'StaatsBrabant' and 'Staats-Vlaanderen', which meant they had the status of a colony of the Dutch Republic. Such areas were called 'Generality Lands' since they were governed by the States- General (the federal government). This category also included overseas areas controlled by the Dutch Republic, such as Staten Island in New York, New Zealand (initially called 'Staten Landt' by its discoverer, Abel Tasman) and Isla de los Estados (a literal translation of the Dutch name 'Stateneiland') off the coast of Argentina.

16. While there were initial differences between North and South, it is clear that 
whatever initial differences existed, they were magnified greatly by the Revolt, which 'can be said to have widened, and reinforced, a duality which had long existed in politics and economic life' (Israel, The Dutch Republic, vi).

17. Israel, The Dutch Republic, 197, 219 and 308.

18. Israel, The Dutch Republic, 307.

19. Roegiers and Van Sas, "Revolutie in Noord en Zuid," 249.

20. Roegiers and Van Sas, "Revolutie in Noord en Zuid," $222-256$.

21. A comparison of Maps 1 and 2 shows that the original dividing line of 1648 is still the border between present-day Belgium and the Netherlands as formed in 1830, with minor exceptions. In the North-Eastern part of Belgium and the South-Eastern part of the Netherlands (the present-day provinces of Limburg in Belgium and Limburg in the Netherlands) Belgium had lost some extra territory to the Netherlands compared to the 1648 border.

22. This is still evident from the Dutch national anthem, which states 'the King of Spain, I have always honored'.

23. Parker, "Why did the Dutch Revolt," 63, 66.

24. Van Deursen, "De Republiek," 148.

25. 't Hart, The Dutch Wars, 1. For an extensive discussion of how the Dutch turned the Dutch Revolt into a commercial success due to the interrelationship between war, the economy and society, we refer to 't Hart, The Dutch Wars; also see Frijhoff and Spies, 1650: Hard-won Unity; Swart, Krijgsvolk; Van Nimwegen, Deser landen Crijchsvolck.

26. Parker, "The Dutch Revolt," 53.

27. 't Hart, The Dutch Wars, 14.

28. 't Hart, The Dutch Wars, 52.

29. Tilly, Coercion, Capital, 78-79.

30. 't Hart, The Dutch Wars, 52.

31. Parker, "The 'Military Revolution'," 200.

32. 't Hart, The Dutch Wars, 33-34 and 52-53.

33. 't Hart, The Dutch Wars, 51.

34. As noted by Parker a comparison of maps of Dutch towns in the 1550s with maps made a century later clearly reveals these changes, Parker, "War and Economic Change," 58.

35. For instance, the Spanish conquest of Haarlem in 1573 required seven months of siege. It took the Spanish 14 months to capture Antwerp in 1585,11 months to capture Breda in 1625, and three years and three months to capture Ostend in 1604. Despite repeated attempts in 1588, 1605 and 1622 the Spanish never managed to capture the town of Bergen-opZoom.

36. Parker, "Why did the Dutch Revolt," 57.

37. For a note on currencies, see the Appendix. For comparability, we have chosen to report all amounts in florins. Drelichman and Voth, "The Sustainable Debts," 24, report the totals for this period in ducats. The average exchange rate for this period is about 2.5 florins to the ducat.

38. This estimate does not even take into account the costs of outfitting the Armada, the 'invincible' fleet sent against England in 1588. Although directed against England, the military reason for this operation was that England had 
been providing support to the Dutch rebels. In this perspective, the Armada should be considered as part of the Spanish attempts to suppress the rebellion in the Low Countries. The costs of the Armada were large: at 28 million florins, outfitting the fleet had cost the equivalent of two years of Spanish tax revenues (Drelichman and Voth, "The Sustainable Debts," 818).

39. Drelichman and Voth, "The Sustainable Debts," 817.

40. Data on revenues of the Spanish army, 1566 - 1648, are taken from Parker, The Army of Flanders, 287 and 293 - 295 using his conversions into florins. Data on Spanish silver inflows, 1571 - 1650, are taken from the European State Finance Database (http://esfdb.websites.bta. com/Database.aspx) using data provided by Gelabert ("Castile, 1504 - 1808"). The numbers from the ESFD have been converted into florins using the procedure outlined in the Appendix.

41. Although Philip II was king of Castile and of Aragon (the two kingdoms forming Spain), Castile was by far the dominant kingdom, accounting for more than $80 \%$ of the population (Drelichman and Voth, "The Sustainable Debts," 816). Hence, we follow Drelichman and Voth in focusing on Castile rather than Spain as a whole.

42. Data from the European State Finance Database indicates that the per capita fiscal burden increased from around 3400 florins in 1591 to 7000 florins in 1631.

43. Between Philip II's accession in 1557 and his death in 1598, the Spanish national debt grew from 36 million ducats to 85 million ducats. It kept growing during the rest of the conflict. By 1623, debt had increased to 112 million ducats, and it would increase further to 180 million ducats in 1667 . We report these numbers in the original currency to allow easier comparison over time; converting into florins would obscure the evolution because of the changing exchange rate between the ducat and the florin. The ducat was worth around two florins in 1557, three in 1598, four in 1623 and three and a half in 1667 (see the Appendix). Not all of this increase in debt can be ascribed to the Dutch Revolt since Spain was involved in several military campaigns throughout the period. However, the Dutch Revolt was the largest item on the Spanish budget, and increases in government debt correspond closely with the periods of greatest war expenditures in the Low Countries. Parker, "War and Economic Change"; Drelichman and Voth, "The Sustainable Debts," 817.

44. Given these extraordinary costs, one may wonder why the Spanish insisted on continuing their campaign against the rebels. It is clear that Spain was not willing to strike a compromise. While the Dutch would have been willing to return to Spanish rule on condition of religious liberty and a restoration of ancient privileges, the Spanish crown would not make any concessions concerning the exclusive position of the Catholic Church or the sovereignty of the king. The Spanish intransigency is probably due to their concern that surrender in the Low Countries would inspire rebellion and heresy in other parts of the Spanish Empire. By showing themselves willing to fight to the utmost, the Spanish hoped to maintain a reputation which would deter such uprisings in the future. Parker, "Why did the Dutch Revolt,"61; 'tHart, The Dutch Wars, 3. 
45. Parker, Spain and The Netherlands, 49.

46. Parker, "The 'Military Revolution'," 212.

47. The average mutiny lasted 189 days, involved 1350 men, and cost the Spanish treasury 241 florins per mutineer in settlement. This was a large sum, considering that the daily wage of a soldier in 1568 was approximately 0.2 florins. This may indicate that wage arrears were large and/or that the army leadership could only end mutinies by paying large bonuses to the mutineers. These numbers have been calculated using the data provided by Parker, The Army of Flanders, Appendix J. The numbers give the median values for the three categories. For the daily wage of a soldier, see Parker, The Dutch Revolt, 110 , who gives the daily wage as 3 or 4 'stuivers' (one florin was 20 stuivers).

48. Likewise, Parker argues that the failure of the Spanish to capture Alkmaar (1573), Leiden (1574) and Zierikzee (1576) was due to mutinies, Parker, Spain and The Netherlands, 49.

49. In 1576, Spanish mutineers made a surprise attack on Antwerp and pillaged the town, killing 8,000 civilians in what became known as the "Spanish Fury" Parker, Spain and The Netherlands, 114.

50. Parker, Spain and The Netherlands, 119.

51. See Appendix B. We do not present similar calculations for Spain, since estimates of Spanish GDP or fiscal pressure are notoriously unreliable, with GDP estimates often varying by a factor of two or more. Alvarez-Nogal and Prados de la Escosura, "The Decline of Spain."

52. By way of comparison, Nordhaus, "The Economic Consequences,"3 7, provides historical data on the costs of various wars in which the United States was involved. Converting his data to annual percentages of GDP shows that the direct costs of war varied between $0.5 \%$ for the First Gulf War $(1990-1991)$ to 26\% during the Second World War (1941 - 1945). The Dutch war effort of around $6-8 \%$ of GDP make the Dutch Revolt on a per-year basis more expensive than the Vietnam war $(1.33 \%$ of GDP, 1964 - 1972) or the Korea war (3.75\% of GDP, 1950-1953).

53. Fritschy, "A 'Financial Revolution'," 59.

54. Fritschy, "A 'Financial Revolution'," 59-63.

55. 't Hart, The Dutch Wars, 324.

56. The figures for Spanish war expenditures may understate the true amount, since these numbers only give the amounts transferred from Spain to the army in the Low Countries and do not include money raised in the Low Countries. However, Parker, The Army of Flanders, notes that transfers from Spain were the most important revenue source for the Spanish army, accounting for some $80 \%$ of expenditures. Even if we assume Spanish expenditures were $25 \%$ higher than the amounts shown here, it would still be the case that Dutch war expenditures considerably exceeded the Spanish budgets in the last three decades of the Revolt.

57. 't Hart, The Dutch Wars, 148.

58. ' t Hart, The Dutch Wars, 148.

59. Feld, "Middle-class Society," 437.

60. Parker, "The 'Military Revolution',"212.

61. 't Hart, The Dutch Wars, 4.

62. Throughout the Revolt, Holland was always responsible for the largest 
share of the war expenditure - around $60 \%$ - followed by Zeeland and Friesland. The situation was remarkably stable: Moreover, Holland's share seems to have been remarkably stable, varying between $66 \%$ in 1585 and $57 \%$ in 1612 . Even as late as 1792 , Holland's share stood at $62 \%$. Together, Holland, Zeeland and Friesland accounted for at least three quarters of total war expenditures, and in the early decades even practically all of it. During the Revolt, the share of Zeeland was between 10 and $15 \%$ while that of Friesland was around $12-13 \%$. Veenstra, Gewestelijke Financiën-Part VII: Zeeland, 15 and 17.

63. No exact data is available from the period of the Revolt, but an indication is given by an overview of payment arrears for the years 1665 and 1666 . While Holland still needed to pay $15 \%$ of its dues, this number varied between $30 \%$ and $88 \%$ in the other provinces. Liesker and Fritschy, Gewestelijke Financiën - Part IV: Holland, 8.

64. De Vries, "Taxing the Staff of Life," 5.

65. 't Hart, The Dutch Wars, 150-151; De Vries and Van der Woude, The First Modern Economy, 93-94.

66. 't Hart, "De prijs van de vrijheid."

67. For instance $78.3 \%$ of total expenditure of Holland went to the war in 1603, $77.8 \%$ in 1625 and 58.8\% in 1648. Fritschy, "A 'Financial Revolution'," 81-82.

68. Fritschy, "A 'Financial Revolution'," 63.

69. Tracy, The Founding, 102 and "Holland's New Fiscal Regime," 42 give a number of $41 \%$ for the combined share of wine and beer. Given wine's status as a luxury good and beer's widespread consumption, it appears realistic that beer accounts for most of this. Van Uytven (1990), "Le vin," notes that the importance of wine in towns' tax revenues declined rapidly from the fourteenth century onwards. Although he does not offer data for towns in Holland, his numbers show that the share of beer in the combined revenues from beer and wine was $70 \%$ in Bruges in 1532, more than $70 \%$ in Antwerp in 1560 and more than $80 \%$ in Leuven in 1569 . Hence, assuming this ratio was $75 \%$ in Holland, this would imply that in the 1570 s, $30 \%$ of total provincial tax revenues came from the excise on beer alone.

70. Tracy, "Holland's New Fiscal Regime," 43.

71. Tracy, The Founding, 103 and "Holland's New Fiscal Regime," 33-34.

72. De Vries, "Taxing the Staff of Life," 1.

73. Veenstra, Gewestelijke Financiën-Part VII: Zeeland, 15.

74. “... sonder dat die selve middelen tot eenige saecken sullen moghen worde bekeert", Liesker and Fritschy, Gewestelijke Financiën - Part IV: Holland, 28.

75. Liesker and Fritschy, Gewestelijke Financiën-Part IV: Holland, 160 and 165.

76. Liesker and Fritschy, Gewestelijke Financiën-Part IV: Holland, 162 and 246.

77. The approach adopted here (following Fritschy, "A 'Financial Revolution"”) counts credit as a revenue source, which is only correct from a liquidity perspective. If loans were not counted as revenue, the share of the common means in total revenues stands at $69 \%$ throughout the Revolt, and beer taxes account for $23 \%$ of "true" revenues. 
78. The increase in tax revenues was partly the result of strong economic growth and a growing population (from about 350,000 in 1544 to about 760,000 in 1648), but also the per capita tax burden increased strongly during this period. Fritschy, "A 'Financial Revolution'," 70. At the start of the Revolt, the tax burden for an urban day-labourer was probably less than 5\%; by 1600 this figure was probably almost $9 \%$, and it would continue to increase to more than $12 \%$. The tax burden for those earning a middle income showed a similar increase. Fritschy, "A 'Financial Revolution'," 70.

79. Joopen-beer was an expensive high quality beer, apparently dark, red-brown and sweet, which originated from Gdansk but was later also brewed in German towns. Unger, A History of Brewing, 317; Tracy, "Holland's New Fiscal Regime, 1572-1576," 44.

80. Unger, A History of Brewing, 314

81. Unger, A History of Brewing, 145-147 and 317-318.

82. Even if we assume that beer taxes during the final three decades of the Revolt (1621-1648) were only half as much as our calculations suggest, it would remain true that Dutch beer amounted to $21 \%$ of Spanish silver tax revenues over the entire course of the Revolt. These calculations only take into account beer taxes in Holland. Although data on the other provinces are harder to find, beer taxes probably played an important role in some of the other provinces as well, most notably in Zeeland. Hence, the estimate presented here should be considered a lower bound.

83. These numbers probably underestimate the actual contribution of beer to the war effort. After Holland, the provinces of Zeeland and Friesland were the largest contributors to the war effort (see endnote 62). Whereas Holland contributed around $60 \%$ of the total war budget of the Dutch Republic, these provinces together accounted for $20 \%$ to $25 \%$. In both provinces, beer seems to have played an important fiscal role as well. For instance, data for the town of Walcheren (Zeeland) shows that beer accounted for $40 \%$ of the 'common means' in 1608, and $21 \%$ in 1650; see Veenstra, Gewestelijke Financiën - Part VII: Zeeland, 102-103. Likewise, in 1650 the beer excise was 33\% of 'common means' revenues in Friesland, see Trompetter, Gewestelijke Financiën-Part VI: Friesland, 83-84 and 95-96.

84. Unger, Beer in the Middle Ages, xiii.

85. Poelmans and Swinnen, "A Brief Economic History," 8, 12; Egmond, "De strijd."

86. Aerts, "Het hoofdelijk bierverbruik," 53.

87. Van Deursen. Plain Lives.

88. Unger, A History of Brewing, 90-92.

89. Colen and Swinnen, "Beer Drinking Nations," 130. It should be noted, however, that beer had lower alcohol content in medieval and Renaissance times.

90. In 1514 , there were 148 breweries in Gouda, a city of 14,000 inhabitants. Haarlem, a city of 11,000 inhabitants, had 77 brewers, while Delft counted 98 brewers on a population of 12,000. Unger, A History of Brewing, 84 .

91. Egmond, "Destrijd."

92. An inelastic demand implies that a price increase due to taxation does not strongly reduce the demand. If a given revenue must be raised via taxes on 
consumption, taxing commodities with an inelastic demand is thus an attractive option. Beer and bread shared many characteristics leading to an inelastic demand, which explains why both were popular sources of revenue. De Vries, "Taxing the Staff of Life," 6.

93. Poelmans and Swinnen, "From Monasteries," 202.

94. Unger, Beer in the Middle Ages, 197.

95. De Vries and Van der Woude, The First Modern Economy, 93.

96. Unger, A History of Brewing, 140 - 148; Unger, Beer in the Middle Ages, 205.

97. Unger, A History of Brewing, 314.

98. Yntema, The Brewing Industry, 174; Unger, Beer in the Middle Ages, 163.

99. Unger, A History of Brewing, 147.

100. Patroons, Bier.

101. Unger, Beer in the Middle Ages, 202.

102. Unger, A History of Brewing, 150- 155; Van Uytven, "Brouwers en drinkers," 36.

103. Unger, A History of Brewing, 133.

104. Unger, Beer in the Middle Ages, 205.

105. Unger, A History of Brewing, 115

106. Yntema, The Brewing Industry, 174; Unger, Beer in the Middle Ages, 163.

107. Unger, A History of Brewing, 151.

108. Unger, A History of Brewing, $148-150$.

109. Unger, Beer in the Middle Ages, 200.

110. Unger, A History of Brewing, 152. Extensive discussion of beer taxes can be found in Unger, A History of Brewing; Unger, Beer in the Middle Ages.

111. Unger, Beer in the Middle Ages, 205.

112. Belgische Brouwers, Het Brouwersblad, December 1993, vol. 100, 18 - 19.

113. De Vries, "Taxing the Staff of Life," 6, 9.

114. For instance: De Vries, "The Political Economy" 85-114 and "Taxing the Staff of Life" 1574-1855", paper for presentation to Yale Economic History Seminar, 23th April 2012, 2012.

115. De Vries, "Taxing the Staff of Life," 1.

116. De Vries, "Taxing the Staff of Life," 7.

117. De Vries, "Taxing the Staff of Life," 3.

118. De Vries, "Taxing the Staff of Life," 3-4. Tax rates depended on the variety of grain. The tax on rye, for instance, was always half of the wheat tax. Other grains such as barley or buckwheat were also subject to the milling tax. De Vries, "Taxing the Staff of Life," 8.

119. Data from Liesker and Fritschy, Gewestelijke Financiën-Part IV: Holland, 160 and 165 (for 1575); 160 and 169 (for 1590); 246 and 259 (for 1608); 162 and 246 (for 1650).

120. As for the beer excise, this estimate is calculated as the unweighted average of the estimates for 1575, 1590, 1608 and 1650 .

121. Liesker and Fritschy, Gewestelijke Financiën-Part IV: Holland, 238 and 246.

122. Unger, A History of Brewing in Holland, $243-244$.

123. As mentioned earlier, institutional reforms of the 1540 s gave more fiscal autonomy to the provinces of the Low Countries. In contrast to Holland, however, Flanders and Brabant (the two leading provinces of the Southern 
Low Countries) did not succeed in developing a coherent financial administration at the provincial level, largely caused by the many different interest groups (such as guilds, corporate institutions, the clergy) that were at stake and that did not want to give up their privileges. In these two provinces, the separate cities, some of which were very powerful, continued to follow their own rules and taxes. 't Hart, The Dutch Wars, 150151.

124. Parker, The Dutch Revolt, 115 -117.

125. Parker, The Army of Flanders.

126. Drelichman, "European State Finance," 11.

127. 't Hart, The Dutch Wars, 165-166.

128. 't Hart, The Dutch Wars, 164.

\section{References}

Acemoglu, D., S. Johnson, and J. Robinson. "Institutions as a Fundamental Cause of Long-Run Growth." In Handbook of Economic Growth, edited by P. Aghion and S. Durlauf. Elsevier, Amsterdam: 385 - 472. 2005.

Aerts, E. "Het hoofdelijk bierverbruik in de zuidelijke Nederlanden (ca. 1400 - 1800) enkele kanttekeningen." Bijdragen tot de geschiedenis: "proeve 't al, 't is prysselyck": verbruik in Europese steden (13de-18de eeuw) 81, no. 1 - 3 (1998): 43 - 60.

Alvarez-Nogal, C., and L. Prados de la Escosura. "The Decline of Spain, 1500 - 1850: Conjectural Estimates." European Review of Economic History 11, no. 3 (2007): 319 - 366.

Belgische Brouwers. Het Brouwersblad, December 1993, vol. 100, 1993.

Blom, J. C. H., and E. Lamberts, eds. Geschiedenis van de Nederlanden. The Netherlands: HBUitgevers, Baarn, 2001.

Bockstette, V., A. Chanda, and L. Putterman. "States and Markets: The Advantage of an Early Start." Journal of Economic Growth 7, no. 4 (2002): 347 - 369.

Colen, L., and J. Swinnen. "Beer Drinking Nations: The Determinants of Global Beer Consumption." In The Economics of Beer, edited by J. Swinnen, 113 - 140. Oxford University Press, Oxford, 2011.

De Vries, J. "The Political Economy of Bread in the Dutch Republic." 
In The Political Economy of the Dutch Republic, edited by O. Gelderblom, 85 - 114. Ashgate, Aldershot, 2009.

De Vries, J. "Taxing the Staff of Life: The Dutch Bread Tax, 1574 1855." Paper for presentation to Yale Economic History Seminar, 23th April 2012.

De Vries, J., and A. Van der Woude. The First Modern Economy:

Success, Failure, and Perseverance of the Dutch Economy, 1500 1815. Cambridge University Press, Cambridge, 1997.

Drelichman, M. "European State Finance, 1348 - 1700: Spain.” In Handbook of Key Global Financial Markets, Institutions, and Infrastructure, edited by G. Caprio, Vol. 1, 259 - 267,

Elsevier, Oxford, 2013.

Drelichman, M., and H. -J. Voth. "The Sustainable Debts of Philip II: A Reconstruction of Castile's Fiscal Position, 1566 - 1596." The Journal of Economic History 70, no. 4 (2010): 813 - 842.

Egmond, F. "De strijd om het dagelijks bier. Brouwerijen, groothandel in bier en economische

politiek in de Noordelijke Nederlanden tijdens de zestiende eeuw." In Ondernemers en bestuurders. Economie en politiek in de Noordelijke Nederlanden in de late Middeleeuwen en vroegmoderne tijd, edited by C. Lesger and L. Noordegraaf, 153 194. Amsterdam, 1999.

Feld, M. D. "Middle-class Society and the Rise of Military Professionalism: The Dutch Army, 1589 - 1609." Armed Forces and Society 1, no. 4 (1975): 419 - 444.

Frijhoff, W., and M. Spies. Dutch Culture in a European Perspective: 1650: Hard-won unity, Uitgeverij Van Gorcum. Assen and Basingstoke, 2004.

Fritschy, W. Gewestelijke Financiën ten tijde van de Republiek der Verenigde Nederlanden. Part I: Overrijsel (1604 - 1795). Instituut voor Nederlandse Geschiedenis, Den Haag, 1996.

Fritschy, W. "A 'Financial Revolution' Reconsidered: Public Finance in Holland during the Dutch Revolt, 1572 - 1648." 
Economic History Review 56, no. 1 (2003): 57 - 89.

Fritschy, W. "The Efficiency of Taxation in Holland." In The Political

Economy of the Dutch Republic, edited by O. Gelderblom, 55 - 84.

Ashgate, Aldershot, 2009.

Gelabert, J. "Castile, 1504 - 1808." In The Rise of the Fiscal State in Europe, c. 1200-1815, edited by R. J. Bonney. Oxford University Press, Oxford, 1999.

Gelderblom, O., and J. Jonker. "Public Finance and Economic Growth: The Case of Holland in the Seventeenth Century." The Journal of Economic History 71, no. 1 (2001): 1 - 39.

Gelderblom, O. The Political Economy Of The Dutch Republic, Ashgate Publishing Limited, Farnham, Surrey, 2009.

Hanson, J. "Forging Then Taming Leviathan: State Capacity, Constraints on Rulers, and Development." International Studies Quarterly, 58, no. 2 (2014): 380 - 392.

't Hart, M. "Staatsvorming, sociale relaties en oorlogsfinanciering in de Nederlandse republiek." Tijdschrift voor Sociale Geschiedenis 16, no. 1 (1990): 61 - 85.

't Hart, M. The Making of a Bourgeois State. War, Politics and Finance During the Dutch Revolt. Manchester: Manchester University Press, 1993.

't Hart, M., J. Jonker, and J. Luiten van Zanden, eds. A Financial History of the Netherlands 1550 - 1990. Cambridge: Cambridge University Press, 1997.

't Hart, M. "De prijs van de vrijheid: de Opstand en de belastingdruk in de noordelijke Nederlanden." In Oorlog \& Samenleving in de Nieuwe Tijd, edited by Raymond Fagel and David Onnekink, 11 28. Maastricht: Shaker Publishing, 2005.

't Hart, M. "De democratische paradox en de Opstand in Vlaanderen, Brabant en Holland." In Bourgondie" voorbij. Opstellen aangeboden aan Wim Blockmans, edited by M. Damen and L. Sicking, 323 335. Uitgeverij Verloren, Hilversum, 2010.

t Hart, M. "Military Events: From the Dutch Revolt to "la Guerre de 
Hollande', c. 1570 - 1680." In The Dutch Wars of Independence: Warfare and Commerce in the Netherlands, 1570 - 1680, edited by M. 't Hart. New York: Routledge, (2014): 12 - 36.

't Hart, M. The Dutch Wars of Independence: Warfare and Commerce in the Netherlands, 1570 - 1680. New York: Routledge, 2014.

Israel, J. The Dutch Republic. Its Rise, Greatness and Fall, 1477-1806. Clarendon Press, Oxford, 1995.

Leisering, W. Putzger Historischer Weltaltlas, 76. Berlin: Cornelsen Verlag, 1997.

Liesker, R., and W. Fritschy. Gewestelijke Financiën ten tijde van de Republiek der Verenigde Nederlanden. Part IV: Holland (1572 1668). Instituut voor Nederlandse Geschiedenis, Den Haag, 2004.

Nordhaus, W. "The Economic Consequences of a War with Iraq." Cowles foundation discussion paper, no. 1387, Yale University 2002.

North, D. "Institutions." Journal of Economic Perspectives" 5, no. 1 (1991): $97-112$.

Nye, J. War, Wine and Taxes: The Political Economy of Anglo-French Trade, 1689 - 1900. Princeton University Press, Princeton, New Jersey, 2007.

Nye, J. "Brewing Nation: War, Taxes, and the Growth of the British Beer Industry in the Eighteenth and Nineteenth Centuries." In The Economics of Beer, edited by J. Swinnen, 62-78. Oxford University Press, Oxford, 2011.

Parker, G. The Army of Flanders and the Spanish Road, 1567 - 1659.

The Logistics of Spanish Victory and Defeat in the Low Countries'

Wars. Cambridge University Press, Cambridge, 1972.

Parker, G. "War and Economic Change: The Economic Costs of the

Dutch Revolt." In War and Economic Development: essays in

memory of David Joslin edited by J. M. Winter, $49-71$.

Cambridge University Press, Cambridge, 1975.

Parker, G. "Why did the Dutch Revolt Last Eighty Years?" 
Transactions of the Royal Historical Society 26 (1976): 53 - 72.

Parker, G. “The 'Military Revolution', 1560 - 1660 - A Myth?” Journal of Modern History 48, no. 2 (1976): 195-214.

Parker, G. Spain and the Netherlands, 1559 - 1659. Enslow Publishers, Berkeley Heights, New Jersey, 1979.

Parker, G. The Dutch Revolt. (revised edition) Penguin Books, London, 1990 (1977). Patroons, W. Bier. Antwerpen: Standaard Uitgeverij, 1979.

Poelmans, E., and J. Swinnen. "A Brief Economic History of Beer." In The Economics of Beer, edited by J. Swinnen, 3 - 28. Oxford University Press, Oxford, 2011.

Poelmans, E., and J. Swinnen. "From Monasteries to Multinationals (and Back): A Historical Review of the Beer Economy." Journal of Wine Economics 6, no. 2 (2011): 196 - 216.

Swart, E. Krijgsvolk. Militaire professionalisering en het ontstaan van het Staatse leger, 1568 - 1590. Amsterdam University Press, Amsterdam, 2006.

Roegiers, J., and N. C. F. Van Sas. "Revolutie in Noord en Zuid (1780 - 1830)." In Geschiedenis van de Nederlanden, edited by J. C. H. Blom and E. Lamberts, 222 - 256. HB Uitgevers, Baarn 2001.

Tilly, C. Coercion, Capital, and European States, AD 990 - 1992. Oxford Blackwell Publishers, Oxford, 1997.

Tracy, J. D. "The Taxation System of the County of Holland during the Reigns of Charles V and Philip II, 1519-1566." Economisch en Sociaal-Historisch Jaarboek 48, no. 2 (1985): 71 - 117 Nijhoff, Den Haag.

Tracy, J. D. The Founding of the Dutch Republic. Oxford University Press, Oxford, 2008.

Tracy, J. D. "Holland's New Fiscal Regime, 1572 - 1576." In The Political Economy of the Dutch Republic, edited by O. Gelderblom, 41 - 54. Ashgate, Aldershot, 2009.

Trompetter, C. Gewestelijke Financiën ten tijde van de Republiek der Verenigde Nederlanden. Part VI: Friesland (1587-1795). Instituut 
voor Nederlandse Geschiedenis, Den Haag, 2007.

Unger, R. A History of Brewing in Holland, 900 - 1900. Economy, Technology and the State. Leiden, Boston and Koln: Brill, 2001.

Unger, R. Beer in the Middle Ages and the Renaissance. University of Pennsylvania Press, Philadelphia, Pennsylvania, 2004.

Van Bavel, B. J. P., and J. L. Van Zanden. "The Jump-start of the Holland Economy During the Late- medieval Crisis, c.1350 c.1500." Economic History Review LVII, no. 3 (2004): 503 - 532.

Van der Ent, L., and W. Fritschy. Gewestelijke Financiën ten tijde van de Republiek der Verenigde Nederlanden. Part II: Drenthe (1602 - 1795). Instituut voor Nederlandse Geschiedenis, Den Haag, 1998.

Van der Ent, L., and V. Enthoven. Gewestelijke Financiën ten tijde van de Republiek der Verenigde Nederlanden. Part III: Groningen (1594 - 1795). Instituut voor Nederlandse Geschiedenis, Den Haag, 2001.

Van Deursen, A. Th. Plain Lives in a Golden Age. Popular Culture, Religion and Society in Seventeenth-Century Holland. Cambridge University Press, Cambridge, 1991.

Van Deursen, A. Th. "De Republiek der zeven verenigde Nederlanden (1588 - 1780)." In Geschiedenis van de Nederlanden, edited by J. C. H. Blom and E. Lamberts, 117 - 177. Baarn: HBUitgevers, 2001.

Van Ham, W. A. "Ontstaan door strijd. De territoria op het gebied van de tegenwoordige provincie Noord-Brabant tussen 1572 en 1795." In Noord Brabant tijdens de Republiek der Verenigde Nederlanden, 1572-1795: Een institutionele handleiding, edited by J. Sanders, 13 - 46. Rijksarchief in Noord-Brabant \& Uitgeverij Verloren's Hertogenbosch, 1996.

Van Leeuwen, B., and J. L. Van Zanden. "Persistent but not Consistent: The Growth of National Income in Holland 1347 1807." Explorations in Economic History 49, no. 2 (2012): 119 -130 . 
Van Leeuwend, B. and Van Zanden, J. L. "The origins of 'Modern Economic Growth'? Holland between 1347 and 1807', working paper, Utrecht University, Utrecht, 15 June, 2010.

Van Nimwegen, O. Deser landen Crijchsvolck: Het Staatse leger en de militaire revoluties 1588 - 1688. Bert Bakker, Amsterdam, 2006.

Van Uytven, R. "Le Vin et la Fiscalite' des Villes." Les Routes de la Treille. Catalogue de l'exposition (Bruxelles, 16 Mars-10 Juin 1990). edited by Caisse générale d'épargne et de retraite (CGER), Galerie CGER, Brussel, 1990, 103 - 117. 1990.

Van Uytven, R. "Brouwers en drinkers." In Waar is de Tijd?: 2000 jaar Leuven en Oost-Brabant, edited by E. Van Ermen; van der Laan, M.; Missotten, G.; van Uytven, R. and Vandekerckhove, V. 35 - 54, Waanders, Zwolle, 2000.

Veenstra, W. Gewestelijke Financiën ten tijde van de Republiek der Verenigde Nederlanden. Part VII: Zeeland (1573 - 1795). Instituut voor Nederlandse Geschiedenis, Den Haag, 2009.

Verstegen, S. W. Gewestelijke Financiën ten tijde van de Republiek der Verenigde Nederlanden. Part V: Utrecht (15791798). Instituut voor Nederlandse Geschiedenis, Den Haag, 2006.

Yntema, R. The Brewing Industry in Holland, 1300 - 1800: A Study in Industrial Development, $\mathrm{PhD}$ Dissertation, University of Chicago, 1992.

Yntema, R. "Een kapitale nering: De Brouwindustrie in Holland tussen 1500 en 1800." In Bier! Geschiedenis van een volksdrank, edited by R. Kistemaker and V. Van Vilsteren, $72-81$. Amsterdam: De Bataafsche Leeuw, 1994. 


\section{Appendix A: Currencies}

During the Dutch Revolt, the principal money of account used in the Dutch Republic was the florin (also called gulden or guilder), which consisted of 20 pattards (or stuivers). The Spanish army in the Low Countries used the gold escudo as principal coin in their bookkeeping. In his work The Army of Flanders, Parker (287), converted these amounts into florins; all amounts referring to the Spanish army in the Low Countries were taken from this source using Parker's conversions.

\begin{tabular}{|l|r|}
\hline Decade & Florins per Ducat \\
\hline $1571-1580$ & 2.18 \\
\hline $1581-1590$ & 2.72 \\
\hline $1591-1600$ & 2.94 \\
\hline $1601-1610$ & 3.14 \\
\hline $1611-1620$ & 3.44 \\
\hline $1621-1630$ & 4.01 \\
\hline $1631-1640$ & 4.05 \\
\hline $1641-1650$ & 3.58 \\
\hline
\end{tabular}

In order to convert other Spanish amounts into florins, we used information on the gold content of coins in Spain and the Low Countries following Drelichman and Voth "The Sustainable Debts", who kindly provided us with the data and the procedure. For example, during the Revolt the gold content of the Spanish escudo was fixed at 3.101 grams of pure gold. Between 1609 and 1642, the escudo was valued at 440 maravedis, while by definition 375 maravedis constituted a ducat. Hence, during this period, the ducat was implicitly valued at 2.643 grams of pure gold. To compare this with the gold content of the florin, we take as a reference a gold coin used in the Low Countries at the time, e.g. the 'Albertin' coin minted between 1610 and 1612. During these years the Albertin contained 2.307 grams of pure gold and was valued at 105 deniers of the Pond Groot Flemish. Since two deniers were equal to one stuiver, this amounts to 52.5 stuivers. There were 20 stuivers 
to the florin, so the florin at the time was valued as the equivalent of 0.88 grams of pure gold. Dividing the 'gold equivalent' of the ducat (2.643 grams of pure gold per ducat) by the 'gold equivalent' of the florin ( 0.88 grams of pure gold per florin), we obtain an exchange rate of 3.1 florins to the ducat. Repeating this procedure for different years gives us the florin-ducat exchange rate during the Dutch Revolt. The following table provides the average exchange rate per decade:

\begin{tabular}{|l|r|}
\hline Decade & Average Exchange Rate \\
\hline $1551-1560$ & $16,202,000$ \\
\hline $1561-1570$ & 23.276 .000 \\
\hline $1571-1580$ & 27.783 .000 \\
\hline $1581-1590$ & 38.435 .000 \\
\hline $1591-1600$ & $62.563,000$ \\
\hline $1601-1610$ & $69.013,000$ \\
\hline $1611-1620$ & 81.242 .000 \\
\hline $1621-1630$ & $98.743,000$ \\
\hline $1631-1640$ & 122.927 .000 \\
\hline $1641-1650$ & $149,004,000$ \\
\hline
\end{tabular}

As a rule of thumb for the early decades, Parker ("Why Did the Dutch Revolt") notes that "there were two florins to the ducat, two florins also to the escudo until 1578 and thereafter two and a half or three', which is consistent with the numbers calculated here.

\section{Appendix B: War Expenditures as a Percentage of GDP,}

\section{Holland}

GDP estimates for Holland are taken from Bas van Leeuwen and Jan Luiten van Zanden, "The Origins of 'Modern Economic Growth'? Holland Between 1347 and 1807', Appendix 1, Table 2.

They report Holland GDP at current prices in florins, by decade: To extrapolate these numbers into a GDP estimate for the entire Republic, we took Holland's quota in the Republic's tax system (which was around 60\%) as a proxy for Holland's share in the Republic's GDP.

In the following table, we combined this information with data 
from 't Hart (1990) on war expenditures by the Dutch Republic for selected years. The GDP numbers are taken from the interval which included this year. For instance, the GDP number for 1586 is the GDP estimate for the years 1581-1590.

\begin{tabular}{|l|c|c|c|}
\hline Year & $\begin{array}{c}\text { Dutch War } \\
\text { Expenditures }\end{array}$ & $\begin{array}{c}\text { Dutch } \\
\text { GDP }\end{array}$ & $\begin{array}{r}\text { \% of } \\
\text { GDP }\end{array}$ \\
\hline 1586 & $2,900,000$ & $64,186,450$ & 4.5 \\
\hline 1600 & $8,200,000$ & $104,480,2$ & 7.8 \\
\hline 1610 & $7,000,000$ & $115,251,7$ & 6.1 \\
\hline 1620 & $9,100,000$ & $135,674,1$ & 6.7 \\
\hline 1630 & $19,000,000$ & $164,900,8$ & 8.8 \\
\hline 1640 & $18,000,000$ & $205,288,0$ & 7.1 \\
\hline
\end{tabular}

Changing the assumption about Holland's share in the Dutch economy does not lead to drastic changes in the share of war expenditures in GDP. For instance, assuming Holland accounted for $80 \%$ of the Dutch economy, war expenditures were $6 \%$ of GDP in $1586,15 \%$ in 1630 , and $9.5 \%$ in 1648. Assuming instead that Holland accounted for only half of the Dutch economy, the corresponding numbers are $3.8 \%$ in $1586,9.6 \%$ in 1630 and $6 \%$ in 1648. 